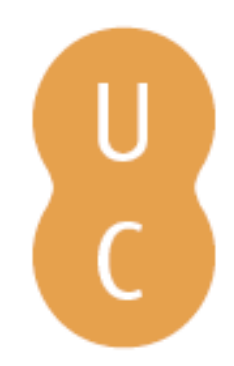

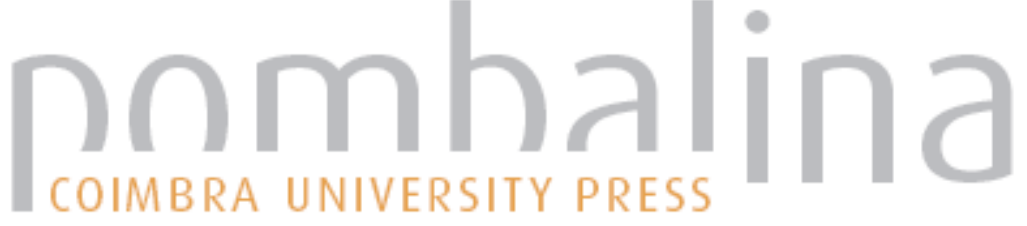

\section{Ifigénia entre os Tauros}

Autor(es): $\quad$ Eurípides; Rodrigues, Nuno Simões, trad., autor da introd., coment.

Publicado por: Imprensa da Universidade de Coimbra; Annablume editora

URL

persistente:

URI:http://hdl.handle.net/10316.2/32826

DOI:

DOI:http://dx.doi.org/10.14195/978-989-26-0837-2

Accessed : $\quad$ 26-Apr-2023 13:57:55

A navegação consulta e descarregamento dos títulos inseridos nas Bibliotecas Digitais UC Digitalis, UC Pombalina e UC Impactum, pressupõem a aceitação plena e sem reservas dos Termos e Condições de Uso destas Bibliotecas Digitais, disponíveis em https://digitalis.uc.pt/pt-pt/termos.

Conforme exposto nos referidos Termos e Condições de Uso, o descarregamento de títulos de acesso restrito requer uma licença válida de autorização devendo o utilizador aceder ao(s) documento(s) a partir de um endereço de IP da instituição detentora da supramencionada licença.

Ao utilizador é apenas permitido o descarregamento para uso pessoal, pelo que o emprego do(s) título(s) descarregado(s) para outro fim, designadamente comercial, carece de autorização do respetivo autor ou editor da obra.

Na medida em que todas as obras da UC Digitalis se encontram protegidas pelo Código do Direito de Autor e Direitos Conexos e demais legislação aplicável, toda a cópia, parcial ou total, deste documento, nos casos em que é legalmente admitida, deverá conter ou fazer-se acompanhar por este aviso. 


\section{EuRÍPIDES}

\section{IFIGÉNIA}

ENTRE

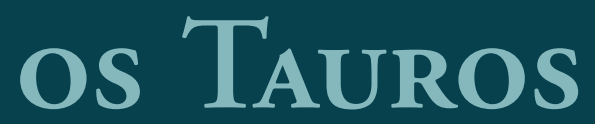

TRADUÇÃO DO GREGO, INTRODUÇÃO E COMENTÁRIO Nuno Simões Rodrigues

IMPRENSA DA UNIVERSIDADE DE COIMBRA COIMBRA UNIVERSITY PRESS 
Apresentação: Esta série procura apresentar em língua portuguesa obras de autores gregos, latinos e neolatinos, em tradução feita diretamente a partir da língua original. Além da tradução, todos os volumes são também caraterizados por conterem estudos introdutórios, bibliografia crítica e notas. Reforça-se, assim, a originalidade científica e o alcance da série, cumprindo o duplo objetivo de tornar acessíveis textos clássicos, medievais e renascentistas a leitores que náo dominam as línguas antigas em que foram escritos. Também do ponto de vista da reflexáo académica, a coleçáo se reveste no panorama lusófono de particular importância, pois proporciona contributos originais numa área de investigaçáo científica fundamental no universo geral do conhecimento e divulgaçáo do património literário da Humanidade.

Periodicidade: trimestral

\section{Estruturas Editoriais}

Coordenadores Gerais (General Editors)

A. Centro de Estudos Clássicos e Humanísticos (Coimbra)

- Delfim Leão (Universidade de Coimbra)

- José Ribeiro Ferreira (Universidade de Coimbra)

- Luísa Portocarrero (Universidade de Coimbra)

- Maria do Céu Fialho (Universidade de Coimbra)

- Sebastiáo Pinho (Universidade de Coimbra)

B. Annablume (São Paulo)

- Gabriele Cornelli (Universidade de Brasília)

- Jacyntho Lins Brandão (Universidade Federal de Minas Gerais)

- Pedro Paulo Funari (Universidade Estadual de Campinas)

Diretor Principal (Main Editor)

- Carmen Leal Soares (Universidade de Coimbra)

- Maria de Fátima Silva (Universidade de Coimbra)

Assistentes editoriais (Editorial Assistants)

- Elisabete Caçáo

- João Pedro Gomes

- Nelson Ferreira

Comissáo Científica (Editorial Board)

- Adriane Duarte (Universidade de São Paulo)

- Aurelio Pérez Jiménez (Universidad de Málaga)

- Graciela Zeccin (Universidade de La Plata)

- Fernanda Brasete (Universidade de Aveiro)

- Fernando Brandáo dos Santos (UNESP, Campus de Araraquara)

- Francesc Casadesús Bordoy (Universitat de les Illes Balears)

- Frederico Lourenço (Universidade de Coimbra)

- Joaquim Pinheiro (Universidade da Madeira)

- Lucía Rodríguez-Noriega Guillen (Universidade de Oviedo)

- Jorge Deserto (Universidade do Porto)

- Maria José García Soler (Universidade do País Basco)

- Susana Marques Pereira (Universidade de Coimbra) 


\section{EURÍPIDES}

\section{IFIGÉNIA}

ENTRE

\section{OS TAUROS}

TRADUÇÃo Do GREGO, INTRODUÇÃo E COMENTÁRIO

Nuno Simões Rodrigues

UNIVERSIDADE DE LISBOA

IMPRENSA DA UNIVERSIDADE DE COIMBRA COIMBRA UNIVERSITY PRESS 
Série Autores Gregos e Latinos • Traduçāo, introdução e comentário

Obra Realizada no Âmbito das actividades Da UI\&D

Centro de Estudos Clássicos e Humanísticos

\section{Título • Ifigénia entre os Tauros}

\section{AUTOR・EUrípIDEs}

\section{Tradução do grego, introdução e comentário • Nuno Simões Rodrigues}

Série Autores Gregos e Latinos • Tradução, introduçấo e comentário

\section{Coedição}

Imprensa da Universidade de Coimbra

URL: http://www.uc.pt/imprensa_uc

E-mail: imprensa@uc.pt

Vendas online:

http://livrariadaimprensa.uc.pt

Annablume editora . comunicaçấo

www.annablume.com.br

\section{CoORdENAÇÃo EDITORIAL}

Imprensa da Universidade de Coimbra

Concepção gráfica e Paginação

Rodolfo Lopes, Nelson Ferreira

INFOGRAFIA

Imprensa da Universidade de Coimbra

\author{
Impressão e Acabamento \\ WWW.ARTIPOL.NET
}

ISSN

2183-220X

ISBN

978-989-26-0836-5

ISBN DigitAL

978-989-26-0837-2

\section{DOI}

http://dx.doi.org/10.14195/

978-989-26-0837-2

Depósito Legal

376708/14

I a EdiçÃo: IUC • 2014

(C) Abril 2014.

Annablume editora - Sáo Paulo

IMPRENSA DA UNIVERSIDADE DE COIMBRA

Classica Digitalia Vniversitatis Conimbrigensis (http://classicadigitalia.uc.pt) Centro de Estudos Clássicos e Humanísticos da Universidade de Coimbra

\section{FCT \\ Fundação para a Ciência e a Tecnologia}

\section{POCI/2010}

Reservados todos os direitos. Nos termos legais fica expressamente proibida a reprodução total ou parcial por qualquer meio, em papel ou em edição electrónica, sem autorizaçâo expressa dos titulares dos direitos. É desde já excepcionada a utilização em circuitos académicos fechados para apoio a leccionaçấo ou extensāo cultural por via de e-learning.

TODOS OS VOLUMES DESTA SÉRIE SÃO SUJEITOS A ARBITRAGEM CIENTÍFICA INDEPENDENTE. 


\section{SUMÁrIo}

INTRODUÇÃO

1. A data

2. A trilogia e o tema 8

3. Estrutura, enredo e sentido do drama 11

4. As personagens 20

5. O texto 24

$\begin{array}{lr}\text { BibLIOGRAFIA SELECTA } & 25\end{array}$

IFIGÉNIA ENTRE OS TAUROS

$\begin{array}{ll}\text { INDEX RERVM } & 101\end{array}$

$\begin{array}{ll}\text { INDEX LOCORVM } & 103\end{array}$

$\begin{array}{ll}\text { INDEX NOMINVM } & 105\end{array}$ 
(Página deixada propositadamente em branco) 


\section{INTRODUÇÁO}

\section{A DATA}

Desconhecemos a datação exacta de Ifigénia entre os Tauros, mas podemos conjecturá-la partindo de outros dados que possuímos acerca da produção euripidiana. Pelo testemunho de Eliano, por exemplo, sabemos que, em 415 a.C., Eurípides ficou em segundo lugar nas Grandes Dionísias, com a trilogia troiana constituída por Alexandre, Palamedes e As Troianas (Eliano, Varia Historia 3.8). Através do método hermenêutico que se baseia na estatística métrica, alguns autores concluíram que Íon, Andrómeda e Helena terão sido compostas em 412 a.C. ${ }^{1} \mathrm{O}$ testemunho de Aristófanes permite-nos confirmar essa data ${ }^{2}$. É ainda o mesmo método métrico que permite concluir também que a Ifgénia entre os Tauros teria sido escrita e produzida entre a trilogia troiana de

${ }^{1}$ Webster, 1967: 163.

${ }^{2}$ Cf. Aristófanes, As mulheres que celebram as Tesmofórias 1059-1061; e os escólios a Lisistrata 962 e a Rãs 53. 
415 e a Helena de 412 a.C., provavelmente em 414 ou 413 a.C. ${ }^{3}$ A nossa tragédia terá sido, portanto, contemporânea de Alcibíades.

\section{A TRILOGIA E O TEMA}

Se as primeiras peças de Eurípides, como Medeia ou Hipólito, se centravam sobretudo em assuntos que giravam em torno dos crimes familiares, as últimas, grupo a que pertence Ifigénia entre os Tauros, preferem os temas construídos sobre as relações familiares, sem que delas, porém, se evidencie o factor crime ou que, pelo menos, esse não tenha o protagonismo do enredo. Assim seria com os dramas que por certo constituíram a trilogia em que esta Ifigénia se incluiu, a saber: Antígona, Ifgénia entre os Tauros, naturalmente, e Héracles Furioso ${ }^{4}$. Nem todos os autores concordam com esta ordem de apresentação, mas o tema da jovem heroína resistente ao poder político instituído, que muito provavelmente daria corpo à Antígona euripidiana, permite-nos considerar que seria esta a peça que alinharia em primeiro lugar, seguindo-se o tema da Ifigénia táurica e a finalizar a história protagonizada por Héracles ${ }^{5}$. Além disso, se a Antígona de Eurípides desenvolvia o conhecido tema sofocliano, mas incidindo sobretudo nas relações da heroína com Hémon e o filho de ambos, Méon, e se o Héracles Furioso se centra nas relaçóes do herói titular com a mulher Mégara e com os filhos, então faz sentido que a Ifgénia entre os Tauros

${ }^{3}$ A tragédia inclui, por exemplo, tetrâmetros trocaicos (1203-1233), métrica que Eurípides usou com regularidade nos últimos doze anos da sua vida. Sobre a datação, ver Webster, 1967: 163, 181; Cropp, 2000: 60, em que se podem ler outros argumentos em defesa desta proposta de datação.

${ }^{4}$ Webster, 1967: 181.

${ }^{5}$ Webster, 1967: 181. 
pertencesse a este grupo, visto que também o argumento desta peça se desenvolve a partir da relação entre os dois irmãos, Ifigénia e Orestes.

O tema essencial da tragédia parte da Oresteia de Ésquilo. Mas Eurípides inova, reescrevendo o mito de Ifigénia e renovando o ciclo dos Atridas. Na trilogia esquiliana, Ifigénia morria em Áulis e o destino trágico da casa de Atreu terminava com a absolvição de Orestes no tribunal de Atenas. Quando escreveu a sua Electra, muito provavelmente alguns anos antes da Ifigénia entre os Tauros, Eurípides manteve o essencial dessa história, em que o matricídio na pessoa de Clitemnestra era apresentado não como um mal necessário mas antes como um erro trágico, derivado da obsessão de Electra com a vingança ${ }^{6}$. Em Ifigénia entre os Tauros, os factores em jogo não são já os mesmos.

O novo argumento parte da tradição que considerava que a jovem Ifigénia, afinal, não tinha morrido no altar do sacrifício, em Áulis. Essa tradição podia ser encontrada em várias fontes. Segundo os Cantos Cíprios, Ártemis teria salvado a filha de Agamémnon, precisamente no momento em que o rei ia sacrificá-la no altar, trocando-a por uma corça e levando-a para a terra dos Tauros, onde teria atingido a imortalidade ${ }^{7}$. Esta era uma tradição que, em parte, se encontrava também no catálogo hesiódico das mulheres, onde se lia que os Aqueus haviam sacrificado uma tal «Ifimede» e que Ártemis a havia substituído no último momento por uma imagem (eidolon), outorgando-lhe depois a imortalidade ${ }^{8}$. Tudo

${ }^{6}$ Cropp, 2000: 36.

7 Cantos Ciprios frs. 32 Davies; 41 Bernabé; ver Jouan, 1966; Hulton, 1962: 364-368.

8 Hesíodo, fr. 23(a) Merkelbach-West. Obviamente, esta história corresponde à de Ifigénia na tradição que encontramos na tragédia em análise. O Catálogo das Mulheres é um texto datado do século VI a.C. 
teria acontecido, porém, na Grécia. Mais tarde, Heródoto identificava a deusa dos Tauros, povo que habitava nas margens do Mar Negro, com a filha do Atrida: «... os Tauros respeitam as práticas seguintes. Sacrificam à deusa virgem os náufragos e os Gregos que capturam nas suas actividades marítimas por este processo; depois de consagrarem a vítima, batem-lhe na cabeça com um maço. Segundo alguns, o corpo lançam-no do promontório cá para baixo (é que o templo está edificado sobre um promontório), e a cabeça espetam-na num madeiro; outros confirmam a versão anterior quanto à cabeça, todavia quanto ao corpo asseguram que eles o não lançam do promontório, mas que o enterram. Esta deusa a quem sacrificam, dizem os próprios Tauros, é Ifigénia, a filha de Agamémnon. Quanto aos inimigos que capturam, é este o tratamento que lhes dão: cortam-lhes a cabeça e levam-na para casa; espetam-na num pau enorme e hasteiam-na bem alto por cima da habitação, sobretudo por cima da chaminé»?. Terá sido com base naquela tradição e nesta referência que Eurípides retomou o ciclo troiano e o reescreveu, dando-lhe um conteúdo que, até entáo, ao que parece, era desconhecido da tragédia ática.

Seja como for, a figura de Ifigénia, além de fazer parte da tradição épica em torno da casa dos Atridas e do ciclo de Tróia, apesar de não ser mencionada na Ilíada ou na Odisseia, integrava também o panteão helénico, associando-se à deusa Ártemis ${ }^{10}$. Pelo que um outro facto poderá ter motivado o poeta a tratar o tema de Ifigénia: a reconstrução do templo de Ártemis em Bráuron, na Ática, e a do túmulo ou Heroon

${ }^{9}$ Heródoto 4.103, em tradução de Maria de Fátima Silva.

${ }^{10}$ Apesar de a Ilíada 9.145, 287, se referir a uma filha de Agamémnon de nome Ifianassa, autores como Cropp defendem que esta e Ifigénia seriam duas personagens distintas, tal como sugerem os Cypria (frs. 17 Davies; 24 Bernabé) e Sófocles, Electra 157, 530-531. 
de Ifigénia, que terá acontecido pouco antes da composição do texto ${ }^{11}$.

Outra importante inovação da tradição mitológica introduzida por Eurípides é a figura de Orestes, que não fazia propriamente parte do ciclo centrado em Ifigénia e Ártemis e que aqui tem um papel determinante. Existe por parte de Eurípides, aliás, uma necessidade de justificar a presença desta personagem no enredo, como provam as duas vezes em que se diz que o filho de Agamémnon e Clitemnestra tinha viajado até à terra dos Tauros por ordem de Apolo, com o objectivo de se apropriar da estátua de Ártemis (7789, 1080). Por outro lado, não está excluída a hipótese de a figura de Orestes ter sido associada ao culto de Ártemis na tradição popular de Halas.

\section{Estrutura, ENREDO E SENTIDO DO DRAMA}

A peça abre com uma Ifigénia exilada em terras bárbaras, na sequência do salvamento operado por Ártemis. Entre os Tauros, povo que habita as costas do Mar Negro no limes da barbárie, Ifigénia desempenha a função de sacerdotisa de Ártemis, deusa que ali assume um carácter sanguinário, pois exige o sacrifício dos estrangeiros que lá chegam. Com ela estão, prisioneiras, outras mulheres de origem helénica, que constituem o coro.

A protagonista começa por assumir o prólogo da peça (1-66), com um extenso monólogo em que recorda tanto o seu passado como as vicissitudes a que a sua família esteve sujeita: a descendência de Atreu, a promessa de Agamémnon em oferecer a Ártemis as primícias do ano, a chegada a Áulis

${ }^{11}$ Sobre esta questão, ver Larson, 1995: 15, 170. 
e a ida para a Táurica ${ }^{12}$. A essa descrição contextualizadora do argumento, Ifigénia acrescenta o sonho recente que lhe sugere a morte do irmão, Orestes. Ficamos assim também a saber que Ifigénia desconhece todos os desenvolvimentos em torno da sua família, desde que foi resgatada por Ártemis em Áulis. De igual modo, ninguém da sua família sabe o que lhe aconteceu. Mas Ifigénia interpreta o sonho de forma errada.

A sacerdotisa retira-se e é então que o jovem Orestes surge em cena, na companhia do primo Pílades (67-122). Os dois amigos e parentes vêm na sequência de um oráculo de Apolo, que ordenou que levassem a estátua de Ártemis do país dos Tauros para o território ateniense. Só assim Orestes conseguirá a tão desejada redenção, que se impõe na sequência do assassínio da própria mãe. Apesar dos medos que se apoderam de Orestes, Pílades convence o primo a continuar com a sua missão, sugerindo que aguardem pelo anoitecer.

Depois da primeira intervenção do coro (123-142, 179-202), e do reaparecimento de Ifigénia em cena, que continua a lamentar-se pela sorte da sua família (143-122, 203-235), chega um boieiro, que vem relatar o que acabou de presenciar na costa, junto à gruta onde os dois primos se haviam refugiado e acabaram por ser encontrados (236-339). A descriçáo que o boieiro faz do comportamento de Orestes é particularmente dramática. O jovem é acometido de ataques de loucura que assustam quem os presencia e pelas suas palavras percebemos que ele se sente perseguido e assombrado pelas Erínias, deusas primordiais da puniçâo dos crimes de sangue. Depois de evocar as várias reacçóes dos tauros que o acompanhavam em tal descoberta, o boieiro considera que os jovens serão duas vítimas sacrificiais ideais para Ártemis, com as quais Ifigénia se vinga do que os próprios Helenos

${ }^{12}$ Sobre o prólogo, ver Hamilton, 1978: 277-302. 
lhe fizeram. Os estrangeiros são então levados à presença da sacerdotisa que, enquanto espera por eles, continua a lamentar a sua sorte ao mesmo tempo que questiona as vontades sanguinárias da deusa (342-391).

Depois de uma segunda intervenção do coro (392-466), Ifigénia recebe os prisioneiros e prepara-se para orientar o seu sacrifício. É então que se dá início a uma das mais extraordinárias cenas de reconhecimento da poesia trágica grega $(467-986)^{13}$. Ifigénia concebe um plano que poderá levar notícias suas aos familiares em Argos. Um dos prisioneiros seria liberto, enquanto o outro alimentaria as necessidades do sacrifício. Depois de Pílades, é Orestes quem acaba por ser o escolhido para o sacrifício. Mas o diálogo em crescendo leva ao clímax, em que o pathos se revela, as personagens se reencontram e a alteração definitiva do curso dos acontecimentos na economia da peça acontece. Orestes é o primeiro a reconhecer a irmã, acabando esta por reconhecer também o irmão que julgava morto. Depois, percebe que Pílades, além de seu primo, é também seu cunhado, visto que está casado com Electra, irmã que ela também não sabia viva. No espaço de poucos minutos, Ifigénia volta a ganhar toda uma família que pensava irremediavelmente perdida e a esperança de regressar a Argos, sua pátria, revitaliza-se. Durante a conversa, surgiu também a revelaçáo da morte do pai e da mãe, mas que no final parece ter um peso pouco significativo no ânimo recuperado de Ifigénia. Para a longa cena do reconhecimento, Eurípides recorre a um estratagema que ficou célebre na literatura grega: as tabuinhas que continham a revelação de tudo e que servem de catalisador para a evoluçáo do enredo ${ }^{14}$.

${ }^{13}$ Aristóteles, Poética 1452b5-7, 1454a7, 1454b31-35, 1455a17-19; ver ainda Cerbo, 1989: 39-47.

${ }^{14}$ Aristóteles, Poética 1452b5-7, 1454b31-35, 1455a17-19. 
Feitas as revelações, e tendo Orestes confessado as suas intençôes ao viajar até à Táurica, cabe a Ifigénia engendrar um estratagema e enganar o rei local para fugir da terra dos Tauros, juntamente com o irmáo e o primo de ambos (989$1074)^{15}$. A sacerdotisa decide comunicar ao rei da terra que as vítimas apanhadas para o sacrifício estáo manchadas por um crime de sangue e que, por isso, há que purificá-las, antes de oferecê-las à deusa. Para isso, os presentes, como todos os habitantes da região, deverão levar a cabo uma série de rituais, para que as vítimas passem pelo processo de purificação. Entre esses rituais conta-se o de tapar os olhos com um véu, enquanto o processo é concluído. Ifigénia faz do coro seu cúmplice. Este intervém de novo (1089-1152) e segue-se a entrada de Toas, rei dos Tauros, em cena.

Perante as explicaçóes que lhe são apresentadas pela sacerdotisa, Toas decide que deve ser feito tudo o necessário para erradicar a mácula da comunidade e encarrega Ifigénia do processo. Esta leva o irmão e o primo para a costa, afirmando ser o mar um elemento de purificação por excelência, mas acarreta consigo a estátua de Ártemis, alegando que a mesma havia sido tocada pelas mãos de quem estava manchado pelo crime de sangue. Enganado, Toas acredita em Ifigénia (1153-1233).

O coro volta a intervir (1234-1282) e é então que entra em cena um mensageiro, que não é mais do que um dos homens de Toas, que acompanhara a sacerdotisa e a procissão que ela guiara à costa. $\mathrm{O}$ mensageiro conta ao rei que tudo não passou de um estratagema de Ifigénia para fugir com a imagem da deusa e os familiares. Naquele que é considerado um dos discursos mais bem compostos de Eurípides, o mensageiro descreve de forma vívida e realista a tentativa de fuga dos

${ }^{15}$ Sobre esta questão ver Hartigan, 1986: 119-125. 
Atridas, no navio que os aguardava, secretamente ancorado nas costas táuricas (1327-1419). Toas decide intervir e evitar a fuga, mas Atena surge em cena, qual deus ex machina, acalma o rei táurico e aconselha-o a desistir de perseguir Orestes, Ifigénia e Pílades, pois os jovens contam com a protecção dos deuses. De seguida, ordena a Orestes que funde em Halas, na costa oriental da Ática, um templo, onde instalará a estátua de Ártemis. Doravante, esta deusa será aí adorada e conhecida como Ártemis Taurópola. Atena fornece ainda as instruçóes para a prática ritual que passará a desenrolar-se em Halas: «sempre que o povo celebrar a festa pelo resgate da tua morte, que se ponha uma espada junto ao pescoço de um homem e se deixe correr o sangue como santificação, pois por meio dele a deusa terá as suas honras.» (1435-1489). Deste modo, Atena confirma a verdadeira missáo de Orestes ao mesmo tempo que o culto sanguinário que Ártemis conhecia entre os Tauros se suaviza e humaniza, ao ser dissociado dos sacrifícios humanos ${ }^{16}$. Quanto a Ifigénia, será consagrada sacerdotisa do santuário de Bráuron, estando-lhe reservadas honras de culto, após a sua morte. Eurípides institui assim uma etiologia para os cultos de Ifigénia e da própria Ártemis, nas regióes de Bráuron e de Halas, bem como para outras festividades atenienses ${ }^{17}$. De algum modo, estes emergem como compensação para a série de males que afinal poderiam ter sido evitados. O facto de ser Atena, a patrona da Ática, a instituir o rito confere uma maior legitimidade ao processo, como se a deusa anunciasse publicamente que recebia a irmã

${ }^{16}$ Como nota Cropp, 2000: 40, a deusa que agora emerge com carácter helénico é compatível com a figura benevolente que surgia nos baixo-relevos de Bráuron, datados do século IV a.C., ainda que o seu potencial destrutivo primitivo continuasse a ser reconhecido tanto no mito como nos ritos. Sobre esta questão, ver Kahil, 1977: 86-98.

${ }^{17}$ Ver Jouan, 1995: 149; Rebelo, 1996: 53-104; Stevens, 1956: 87-94; Wolff, 1992: 308-334. 
Ártemis no seu seio, sendo-lhe devidos culto e devoção de igual importância.

A peça termina com a partida dos Atridas das terras táuricas, acompanhados por Atena, ao mesmo tempo que Toas renuncia à ira e permite o regresso também das servas do coro para a Hélade. Este final confere às personagens de Ifigénia e Orestes a libertaçấo e a redenção, i.e., destinos diferentes daqueles que o ciclo dos Atridas por norma lhes atribuía $^{18}$. As próprias Erínias acabarão por se juntar às suas irmãs, na forma de Euménides, no santuário que lhes foi reservado em Atenas.

O tema da bárbarie, que se reflecte na figuraçáo colectiva dos Tauros, deve ser visto com particular atenção, pois é dele que se retira o sentido do drama. A oposição entre Heleno e Bárbaro faz aqui toda a diferença. É ao Outro/ Bárbaro que o poeta atribui práticas condenadas pelos Gregos do tempo de Eurípides, como os sacrifícios humanos, a ausência da ideia de hospitalidade, a selvajaria em geral. O ambiente do território inóspito, cujas descriçóes resvalam o locus horrendus, adequa-se às vivências que as personagens helénicas ali encontram. Note-se como para chegar a esse país há que passar as célebres e sombrias Simplégades, rochedos que esmagavam todos os navios que por entre elas tentavam atravessar o mar e que funcionam como imagem do mundo que está além do controlável ou do "civilizado» ${ }^{19}$. A parcialidade de Eurípides nesta questão é aliás indiscutível, como se comprova pelo passo em que Toas se refere aos do seu próprio povo como «bárbaros» ${ }^{20}$. Por outro lado, a simplicidade do espírito táurico, como mostram os caracteres

${ }^{18}$ Cropp, 2000: 31 .

${ }^{19}$ Vv. 244, 263, 355, 1389.

${ }^{20}$ V. 1170. Ver Silva, 2005: 194-198; Saïd, 1984: 27-53; Sansone, 1975: 283-295. 
do boieiro, do mensageiro e do próprio rei, tanto confirmam como contrastam com a ideia de bárbarie.

Os vários acontecimentos são dominados pela presença da tyche, a "sorte» ou "fortuna». Como notaram Cropp e outros autores, em Ifigénia entre os Tauros, a tyche permanece obscuramente ligada ao poder e à vontade dos deuses, não assumindo aqui o papel de uma divindade mas antes o do factor inesperado, da contingência derivada de um intrincado complexo de acontecimentos, com os quais os seres humanos têm de lidar recorrendo à flexibilidade e à iniciativa ${ }^{21}$. Efectivamente, as personagens deste drama não só colaboram como adaptam a sua existência às vicissitudes da tyche, procurando sempre tirar o melhor partido das contingências.

Em grande medida é também a tyche a responsável por uma sensação de optimismo que atravessa a peça a partir de determinado passo. A esperança do regresso à pátria perdida, da salvação e do reencontro com os que se ama conferem essa característica pouco usual em Ésquilo ou em Sófocles, por exemplo, ou até mesmo noutros textos euripidianos. $\mathrm{O}$ conjunto destes factores acaba por dar origem a uma peça em que a dimensão trágica inerente ao conflito se encontra com o optimismo da redenção, atingindo o equilíbrio.

$\mathrm{O}$ facto de a tyche não ser entendida propriamente como uma divindade, não significa que não haja nesta Ifigénia um forte sentimento de religiosidade. Antes pelo contrário. O religioso é fulcral e omnipresente nesta peça. Ideias como mácula, ritual, purificação, ablução, juramento, sacrifício, vítima sacrificial não só são axiais como constituem um corpus de informação privilegiado para o estudo da religiáo no tempo de Eurípides.

${ }^{21}$ A presença da tykhe na peça é frequente, como se pode atestar pelos versos 89, 475, 478, 489, 501, 648, 838, 867, 875, 907, 909, 1065, 1067. Ver Cropp, 2000: 37; Rebelo, 1995: 165-186. 
Mas as inovaçóes euripidianas vão mais longe, reflectindo-se nos motivos dramáticos e narrativos, na forma de introduzir o tema do sonho bem como as lamentaçóes, ou na apresentaçáo dos discursos que descrevem os acontecimentos fora de cena. Chegam inclusive ao ponto de oferecer ao espectador temas usualmente próximos da epopeia e do romance, mas pouco habituais na tragédia, como são os combates ou o motivo do herói que chega a uma terra longínqua e misteriosa para encontrar viva uma irmá que julgava morta ${ }^{22}$. Este é, aliás, um elemento comum à Helena: numa peça como na outra, o enredo gira em torno de uma heroína exilada em terras bárbaras e exóticas, onde acaba por reencontrar um ente-querido que acabará por salvá-la.

Aristóteles recorreu à Ifigénia entre os Tauros como exemplo para o que considerava dever ser o esboço geral de um enredo, considerando-a, eventualmente, como uma tragédia complexa ${ }^{23}$. Mais recentemente Cropp classificou esta estrutura como "ingénua», uma vez que a acção se centra apenas em dois blocos, tal como acontece, aliás, com outras peças tardias do poeta: em primeiro lugar, temos a série de acontecimentos que culmina no reconhecimento ou anagnorisis; depois, a peripeteia ou alteração radical do curso dos acontecimentos para o seu reverso, derivada do reconhecimento ${ }^{24}$. Enquanto tema, este remontava à Odisseia, em que grande parte do enredo se constrói em torno do reencontro de Ulisses com os membros da sua casa. Por conseguinte, este era um elemento de particular agrado para

22 Silva, 2005a: 224-225; Caldwell, 1974-1975: 23-40.

23 Aristóteles, Poética 1455b3-15, 1455b32-33, onde se lê que na tragédia complexa tudo é peripécia e reconhecimento; ver White, 1992: 221-240.

${ }^{24}$ Cropp, 2000: 33; Burnett, 1971: 47-72; cf. Aristóteles, Poética 1450a34, 1452a22-14. 
a audiência grega. Nesta tragédia do autor, o reconhecimento assume uma importância de tal forma capital (talvez seja mesmo a peça de Eurípides em que este elemento tem maior relevância) que ocupa cerca de um quarto de todo o texto.

Inevitavelmente, os motivos enunciados trazem à colação a problemática da tragicidade de Iffgénia entre os Tauros. Na verdade, também nesse domínio podemos afirmar que Eurípides não é menos inovador. Sobre todo o argumento paira a incómoda presença da futilidade. Ifigénia está viva. Como tal, a morte de Agamémnon foi escusada, pois náo havia necessidade de Clitemnestra se vingar. Por conseguinte, também a morte desta foi em vão e Orestes sofre desnecessariamente. Em resumo: tudo podia ter sido evitado, tudo não passou de um grande equívoco que, todavia, não impediu grandes sofrimentos e a destruição de praticamente todos os membros de uma grande família. Esta linha de desenvolvimento manter-se-á também na Helena, peça em que a rainha de Esparta está no Egipto e inocente dos acontecimentos que desencadearam a Guerra de Tróia. Também esta, portanto, não foi mais do que um grande equívoco, passando a futilidade e a vanidade a dominar toda a tragédia.

Quanto a considerar-se ou não este drama como tragédia, há que referir que essa não é uma discussão inusitada no âmbito do corpus euripidiano. Ela coloca-se igualmente para outros textos, como a Alceste, o Íon ou a Helena. Muitas têm sido as tentativas de classificação desta Ifigénia, tendo o texto sido já rotulado de romântico, pró-satírico, melodramático, cómico e tragicómico ${ }^{25}$. Tal variedade advém também do facto de sabermos pouco acerca da definição absoluta de tragédia para o tempo de Eurípides. Desconhecemos, por

${ }^{25}$ Cropp, 2000: 42. 
exemplo, se o tom humorístico estava totalmente excluído do que se entendia por tragédia nessa época. $\mathrm{O}$ mais provável é que o texto trágico fosse muito além das normas prescritas por Aristóteles na Poética. Além disso, para um ateniense do século $\mathrm{V}$ a.C., uma peça com as características da Ifigénia entre os Tauros e apresentada no contexto das Grandes Dionísias seria, por certo, inquestionavelmente considerada uma tragédia. Lá continuam presentes temas como a vulnerabilidade humana e o conflito gerado por forças superiores, por exemplo, e sobretudo um mito/ enredo protagonizado pelos grandes heróis do património grego. Por fim, há a referir que não está fora de questão que Eurípides fosse um experimentalista, ensaiando novas formas de representar e exprimir a tragicidade.

A terminar esta rubrica, refira-se que, ainda que a chamada "lei da três unidades» da tragédia não seja uma realidade teorizada de facto na Antiguidade, ou sequer comprovada nos textos que conhecemos, na Ifigénia entre os Tauros existe unidade de acção e de tempo, apesar das constantes remissóes para o passado. Quanto à unidade de espaço, ela não existe propriamente no enredo em si, uma vez que a acção passa do sítio onde se localiza o templo de Ártemis para a costa taúrica. Mas a pragmática faria do primeiro o espaço de toda a representação, uma vez que tudo o que acontece fora dali limita-se a ser narrado.

\section{As PERSONAGENS}

Quanto às personagens, a protagonista é sem dúvida Ifigénia. A melhor definição da sacerdotisa pode ser encontrada nas suas próprias palavras: «solteira, sem filhos, sem pátria, sem amigos» (agamos, ateknos, apolis, 
aphilos, 220). I.e., Ifigénia lamenta tudo o que é e que não conseguiu ser, correspondendo a uma fórmula que enuncia os opostos do cidadão ideal na Atenas do século V a.C., das mulheres em particular: não conhecer a maternidade ou não constituir família, não contrair matrimónio, não ter terra ou comunidade a que pertencer. Mas Ifigénia é uma figura centrípeta, senhora de uma força inegável, uma composição ao nível das melhores personagens femininas de Eurípides. Também ela, aliás, pode ser evocada como contraditório para a alegada misoginia do poeta ${ }^{26}$. A força da mulher vê-se não só na forma como resiste no exílio, junto das suas compatriotas, como na inteligência e na sagacidade. Não esqueçamos que é a Ifigénia que se deve o estratagema para enganar Toas e para a fuga, que o irmão parece incapaz de congeminar.

Quanto a Orestes, parece-nos claro que, apesar da missão que decide cumprir por ordem de Apolo, nem sempre é um modelo de coragem ou de resoluçâo. Parte dos diálogos que mantém com a irmã insere-se na tipologia euripidiana de pôr em cena uma mulher forte e um homem "fraco», como acontece na Medeia, na Electra ou na Hécuba, por exemplo. Talvez resultado do tormento por que passa «às mãos» das Erínias, Orestes não só não encontra a saída desejada para escapar da Táurica, como chega a vacilar na sua determinação, ainda que não hesite em morrer no lugar do parente. Em contrapartida, Pílades, que acima de tudo é o companheiro do infortúnio de Orestes, não desiste e alimenta o ânimo do primo quando este parece falhar. É igualmente à figura de Pílades que devemos alguma dose de humor. De facto, o momento em que o jovem aceita as tabuinhas das mãos da sacerdotisa e as deposita, logo de imediato, nas de Orestes não nos deixa indiferentes. A philia funciona

${ }^{26}$ Ver e.g. Silva, 2007. 
como o elemento unificador destas três personagens. Como facilmente percebemos, todas elas estão dispostas ao autosacrifício em benefício das outras, contrastando fortemente com o ambiente de homicídio familiar que predominava em perspectivas anteriores, designadamente em Ésquilo ${ }^{27}$.

Como referimos, Toas caracteriza-se sobretudo pela "simplicidade de espírito", que de algum modo contrasta com a sua condição de rei e até certo ponto de bárbaro, visto que dele esperaríamos alguma «selvajaria» ou «brutalidade». Mas Toas é o homem que ouve a sacerdotisa da divindade da terra, honrando-a e reconhecendo-lhe a autoridade de quem tem contactos privilegiados com o divino. $\mathrm{O}$ rei chega mesmo a dizer-lhe: «Sábia te criou a Hélade! Com bom discernimento» (1180). Essa "passividade» só se altera no final, precisamente quando a ira derivada do reconhecimento do dolo toma conta do seu espírito. Mas Atena parece não ter grandes dificuldade em acalmar o rei.

Nesta mesma linha vêm o boieiro e o mensageiro, que cumprem as funçôes bem euripidianas de «narrar» acontecimentos que funcionam como catalisadores da peça. Em vez de guerreiros selvagens, todavia, encontramos um camponês e um soldado, típicas personagens anónimas, que olham para o mundo à sua volta com os olhos de homens rudes e rústicos, que exprimem os seus medos e ansiedades de forma adequada ao seu estatuto. Isso não impede, contudo, que Eurípides tivesse escrito para eles alguns dos seus melhores passos dramáticos, designadamente a longa fala do mensageiro (1326-1419).

O coro, constituído pelas prisioneiras gregas, eventualmente mulheres de elevado estatuto social, como se sugere a determinado passo (1140-1150), é um reflexo da

${ }^{27}$ Sansone, 1975: 283-295. 
própria Ifigénia. É também pelo coro que Eurípides transmite a sua percepção da ingrata condição servil. Personagem colectiva, o coro assume um papel relevante na acção. São as servas que, apesar de conhecerem o estratagema de Ifigénia, se decidem pela cumplicidade, correndo risco de vida perante o rei dos Tauros. O mensageiro, aliás, acusa-as disso mesmo (1299). A sua cumplicidade mantém-se inalterável quando conseguem atrasar a perseguição de Toas. Nas decisôes finais de Atena, também elas são contempladas, acabando por lhes ser autorizado o táo desejado regresso à Hélade. Por outro lado, o coro é excluído da cena central do reconhecimento, o que parece querer dizer que o eixo da acçáo se faz girar em torno de Ifigénia e de Orestes, secundarizando definitivamente este elemento.

Apesar de não intervir directamente, a presença de Apolo é constante nesta tragédia. Curiosamente, o resumo antigo que dela nos chegou incluía mesmo o deus de Delfos como personagem da peça, sem que, contudo, ele sequer apareça de facto em cena ou tenha direito a qualquer fala. A necessidade da sua presença justifica-se com o protagonismo que tivera na Oresteia, que o tinha como um dos deuses intervenientes no desenlace do processo de Orestes. Aqui, Apolo é sobretudo o deus oracular e justiceiro, próximo da vontade de Zeus, que motiva o reencontro das personagens, e cuja importância se acentua pelo facto de ser o deus-irmão de Ártemis, a divindade que efectivamente está no eixo do argumento. Em última análise, cremos mesmo poder afirmar que Ifigénia entre os Tauros é sobretudo uma peça acerca de Ártemis, sobre o seu mito e o seu rito ${ }^{28}$. Curiosamente, ainda que constante na peça, esta tem uma presença totalmente passiva. É Atena aliás quem assume o relevante papel de

${ }^{28}$ Lloyd-Jones, 1983: 87-102; Sourvinou-Inwood: 1997: 171-175. 
deus ex machina, o que lhe dá direito a uma fala decisiva na economia do texto. $\mathrm{O}$ seu "protagonismo» deriva do facto de Atenas e os Atenienses serem as referências de facto importantes, relativamente à instituição do culto de Ártemis Braurónia e de Ifigénia Táurica ${ }^{29}$.

Ifigénia entre os Tauros conheceu um êxito significativo na História da Cultura Ocidental, designadamente ao nível da recepção do tema. Em 1779, Goethe compôs a sua própria Iphigenie auf Tauris, em prosa, voltando a ela em 1786, ano em que a reescreveu em verso. No mesmo ano de 1779, Gluck compôs a sua Iphigénie en Tauride, ópera que teve o libretto de François Guillard. Quer a peça de Goethe quer a ópera de Gluck são obras-primas do património ocidental.

\section{5. О теXто}

Resta-nos referir que, para esta tradução, utilizámos o texto grego estabelecido e editado por J. Diggle, no segundo volume das Euripidis Fabulae, editado na Scriptorum Classicorum Bibliotheca Oxoniensis (Oxford University Press, 1981; 4a impressão, 1992) ${ }^{30}$.

${ }^{29}$ Rebelo, 1992; Rebelo, 1996.

30 Cumpre-nos agradecer à Senhora Professora Doutora Maria de Fátima Sousa e Silva a cuidada revisão desta tradução, bem como as sugestóes que fez ao longo de todo o processo. Eventuais incorrecçóes que persistam são, como é evidente, da nossa inteira responsabilidade. 


\section{BibliografiA SELECTA}

\section{A) EdiçóEs CRÍTICAS}

Cropp, M. J., 2000, Euripides, Iphigenia in Tauris, edited with an introduction, translation and commentary by M. J. Cropp, Warminster, Aris \& Phillips, Ltd.

Kovacs, D., 1999, Euripides, Trojan Women, Iphigenia among the Taurians, Ion, ed., transl., D. Kovacs, Cambridge, Mass., and London, Loeb Classical Library.

Sansone, D., 1981, Euripides, Iphigenia in Tauris, ed. D. Sansone, Leipzig, Bibliotheca Teubneriana.

в) Estudos

Albini, U., 1983, «L'Ifigenia in Tauride e la fine del mito», PP 209, 105-112.

Belpassi, L., 1988, "L’Oreste “Taurico” e l'efebia. Alcune considerazioni sui vv. 67-122 della Ifigenia in Tauride di Euripide», QUCC 30, 117-121.

__ 1990, «La "follia” del genos. Un’analisi del "discorso mitico" nella Iffgenia Taurica di Euripide», QUCC 34, 53-67.

Bordaux, L., 1992, «Exil et exilés dans la tragédie d'Euripide», Pallas 38, 201-215.

Buxton, R., 1992, «Iphigénie au bord de la mer», Pallas 38, 209-215. 
Caldwell, R., 1974-1975, «Tragedy Romanticized: The Iphigenia Taurica», CJ 70, 23-40.

Cerbo, E., 1989, «La scena di riconoscimento in Euripide: dall'amebeo alla monodia», QUCC 33, 39-47.

Cropp, M., 1979, «Iphigeneia in Tauris 258-9», Hermes 107, 249-252.

Dowden, K., 1989, Death and the Maiden. Girl's Initiation in Greek Mythology, London, Routledge.

Fabrini, P., 1980, «Note al secondo stasimo dell' Ifigenia Taurica», Dioniso 51, 119-123.

François-Garelli, M.-H., 1991, «A propos d' Iphigénie en Tauride d'Euripide: rencontre avec Adel Hakim", Pallas 37, 79-88.

Hall, E. M., 1987, «The Geography of Euripides' Iphigeneia among the Taurians", AJPh 108, 427-433.

Hamilton, R., 1978, «Prologue Prophecy and Plot in Four Plays of Euripides», AJPh 99, 277-302.

Hartigan, K. V., 1986, «Salvation via Deceit: A New Look at the Iphigeneia at Tauris", Eranos 84, 119-125.

1991, Ambiguity and self-deception: the Apollo and Artemis plays of Euripides, Frankfurt, Peter Lang.

Haslam, M., 1977, «Iphigeneia's Putative Last Words», AJPh 98, 246.

Hulton, A. O., 1962, «Euripides and the Iphigenia Legend», Mnemosyne 15, 364-368.

Jouan, F., 1995, «Les légendes étiologiques chez Euripide», Humanitas 47, 139-150. 
Kahil, L., 1965, «Autour de l'Artémis attique», Antike Kunst 8, 20-33.

- 1977, «L'Artémis de Brauron: Rites et Mystère», Antike Kunst 20, 86-98.

Larson, J., Greek Heroine Cults, Madison, University of Wisconsin Press.

Lee, K. H., 1969, "Euripides, Iphigenia in Tauris 754», Philologus 113, 273.

Lloyd-Jones, H., 1983, «Artemis and Iphigeneia», JHS 103, 87-102.

Masaracchia, E., 1984, «Ifigenia Taurica: un dramma a lieto fine?», QUCC 18, 111-123.

Matthiessen, K., 1964, Elektra, Taurische Iphigenie und Helena. Untersuchungen zur Chronologie und zur dramatischen Form im Spätwerk des Euripides, Göttingen, Vandenhoeck und Ruprecht.

Mckay, K. J., 1964, «The Fury's Coats», Mnemosyne 17, 384385.

O'Brien, M. J., 1988, «Pelopid History and the Plot of Iphigenia in Tauris», CQ 38, 98-115.

Rebelo, A. M. R., 1992, Mito e culto de Ifigénia Taúrica, Coimbra, Dissertação de Mestrado em Literatura Grega apresentada à Faculdade de Letras da Universidade de Coimbra.

- 1994, "O contributo do mito de Ifigénia, na sua versão da Ifigénia entre os Tauros, para a interpretação da Oresteia», Humanitas 46, 75-109. 
1995, «O deus ex machina e o conceito de tyche na economia de Ifigénia entre os Tauros, à luz da teoria aristotélica», Humanitas 47, 165-186.

- 1996, "A Ifigénia entre os Tauros de Eurípides e a prática religioso-cultual ateniense», Mathesis 5, 53104.

Saïd, S., 1984, "Grecs et barbares dans les tragédies d'Euripide. La fin des différences?», Ktema 9, 2753.

Sansone, D., 1975, "The Sacrifice-Motif in Euripides' Iphigenia in Tauris», TAPhA 105, 283-295.

1978, "A Problem in Euripides' Iphigenia in Tauris», RhM 121, 35-47.

- 1979, "Notes on the Iphigenia in Tauris of Euripides», Maia 31, 237-244.

Silva, M.F., 2005, «Representaçōes de alteridade no teatro de Eurípides: o bárbaro e o seu mundo» in M. C. Fialho, M. F. S. Silva, M. H. da Rocha Pereira, coord., Génese e consolidaçâo da ideia de Europa. Vol. I: de Homero ao fim da época clássica, Coimbra, Imprensa da Universidade, 187-237.

2005a, "Expressão dramática do tema "viagem”. A Ifigénia entre os Tauros de Eurípides» in M. F. S. Silva, Ensaios sobre Euripides, Lisboa, 223-242.

2007, "Eurípides misógino" in F.J. Campos Daroca et al., eds., Las personas de Euripides, Amsterdam, Hakkert, 133-190.

Sourvinou-Inwood, C., 1997, «Tragedy and Religion: 
Constructs and Readings» in C. Pelling, ed., Greek Tragedy and the Historian, London, Oxford, 161-186.

Stevens, P. T., 1956, «Euripides and the Athenians», JHS 76, 87-94.

White, S. A., 1992, "Aristotle's favorite tragedies» in A.O. Rorty, ed., Essays on Aristotle's Poetics', Princeton, University Press, 221-240.

Wolff, C., 1992, «Euripides' Iphigenia among the Taurians: Aetiology, Ritual, and Myth», Class. Antiq. 23, 1992, 308-334. 
(Página deixada propositadamente em branco) 


\section{IFIGÉNIA ENTRE OS IAUROS}




\section{Resumo de IFIGÉNIA ENTRE OS TAUROS}

Depois de chegar com Pílades à terra dos Tauros, na Cítia, em obediência a um oráculo, Orestes tenta roubar a imagem de madeira de Ártemis que era honrada no lugar. Ao sair da nau, a loucura domina-o, sendo apanhado e levado por indígenas, juntamente (5) com o amigo. De acordo com o costume, deveria ser oferecido como vítima no santuário de Ártemis, pois os estrangeiros que ali desembarcavam eram sacrificados.

A cena do drama localiza-se entre os Tauros, na Cítia. O coro é composto por mulheres helénicas (10), servas de Ifigénia. Ifigénia diz o prólogo.

As personagens do drama são: Ifigénia, Orestes, Pílades, o coro, um boieiro, Toas, um mensageiro, Atena [e Apolo] ${ }^{1}$.

\section{Pessoas do DRAma}

Ifigénia

Orestes

Pílades

Coro

Boieiro

Toas

Mensageiro

Atena

\footnotetext{
${ }^{1}$ Referido no resumo, não aparece porém em cena.
} 


\section{(Em frente ao templo de Ártemis, na Táurica. Ifigénia sai do templo.)}

\section{IFIGÉNIA}

Quando Pélops, o Tantálida, veio para $\mathrm{Pisa}^{2}$ com os seus velozes corcéis, desposou a filha de Enómao ${ }^{3}$, que deu à luz Atreu. Atreu teve dois filhos, Menelau e Agamémnon, de quem eu, (5) Ifigénia, sou filha, e filha também da Tindárida ${ }^{4}$. Sou aquela a quem o próprio pai imolou, ou assim lhe pareceu, a Ártemis, por causa de Helena, nos gloriosos vales de Áulis,

\section{${ }^{2}$ Cidade da Élide.}

${ }^{3}$ A filha de Enómao era Hipodamia. Apesar de dotada de grande beleza, o pai não a queria casar, pois um oráculo havia anunciado que ele morreria às máos do genro. Segundo outra versão, o próprio pai ter-se-ia apaixonado pela filha. De modo a afastar os pretendentes, Enómao imaginara um estratagema, em que prometia a mão da filha ao vencedor de uma corrida de carros. O pretendente levaria a jovem no seu carro, enquanto o pai, correndo só, tentaria alcançar a filha e o respectivo pretendente. Além de possuir cavalos bastante rápidos, o peso que Hipodamia provocava no carro adversário, bem como a distracção que suscitava, levavam a que o pretendente perdesse a corrida. Uma vez vencedor, Enómao decapitava o pretendente. Foi Pélops quem conseguiu subverter o estratagema, com a ajuda da própria Hipodamia. Quando se apresentou a concurso, a jovem enamorou-se dele e decidiu ajudá-lo a ganhar a corrida através da sabotagem do carro do pai, o que acabou por acontecer. Além do mais, apesar de os cavalos de Enómao terem sido um presente de Ares, os de Pélops haviam sido também um presente de Posídon. O mito de Pélops acabou por se relacionar com a origem dos Jogos Olímpicos. Sobre este mito, ver Ilíada 2, 104-108; Píndaro, Ode Olímpica 1, 40-90; Sófocles, Electra 504ss.; Eurípides, Orestes 988ss.; Apolodoro, Biblioteca 3, 10, 1: Ovídio, Heróides 8, 70; Higino, Fábulas 84, 253; e M.J. O’Brien, «Pelopid History and the Plot of Iphigenia in Tauris», CQ 38, 1988, 98-115; J. Larson, Greek Heroine Cults, Madison, 1995; S. Blundell, M. Williamson, The Sacred and the Feminine in Ancient Greece, London, 1998, 20-22; W. Hansen, "The Winning of Hippodameia», TAPhA 130, 2000, 19-40.

4 Clitemnestra era filha de Tíndaro. 
junto ao mar de azul sombrio; o mar que o Euripo ${ }^{5}$ faz muitas vezes enrolar-se num turbilhão de água, por acção do vento incessante. (10) Foi nesse lugar que o soberano Agamémnon reuniu a frota grega de mil naus, pois queria ganhar para os Aqueus a coroa da vitória sobre Ílio e agradar a Menelau, vingando assim a ofensa que Helena fez ao casamento. (15) Ventos terríveis, porém, tornaram impossível a navegação, o que o levou a ordenar que se consultassem as vítimas. Calcas disse-lhe então: «Ó soberano comandante da Hélade, as naus não sairão desta terra enquanto não tomares como vítima a tua filha Ifigénia e não a ofereceres a Ártemis. (20) Outrora, prometeste à deusa portadora $\mathrm{da} l \mathrm{uz}^{6}$ o sacrifício da mais bela primícia do ano. E eis que, em tua casa, a tua esposa Clitemnestra deu à luz uma criança.» - fazia assim cair sobre mim o preço da beleza - «Pois é essa criança que é devida à deusa em sacrifício.» Foi Ulisses quem maquinou separar-me da minha mãe, sob o pretexto de me casar com Aquiles. (25) Vim para Áulis, pobre de mim, onde me puseram sobre o fogo, prontos a ferir-me com o punhal. Ártemis, porém, arrebatou-me, deixando no meu lugar, aos Aqueus, uma corça; transportou-me depois pelo éter brilhante (30) e trouxe-me para esta terra dos Tauros, em que agora vivo ${ }^{7}$. Toas, o bárbaro que recebeu esse nome por ter pés rápidos como asas ${ }^{8}$, governa aqui sobre bárbaros. Instalou-me como sacerdotisa no templo, em que a deusa Ártemis se compraz com estes costumes, (35) festividades que de belo apenas têm o nome (quanto ao resto, calo-me, por temor à deusa). [Na verdade, ofereço em sacrifício todo o grego que chega a esta

${ }^{5}$ Estreito da Beócia, perto de Áulis, onde sopravam os ventos Bóreas e Antibóreas.

6 Ártemis.

${ }^{7}$ A Crimeia, nas margens do Mar Negro.

${ }^{8} \mathrm{O}$ verbo thoazo significa "mover-se com rapidez» e o adjectivo thoos «rápido» ou «ágil». 
terra, de acordo com um antigo costume da cidade.] (40) Cabe-me cumprir as cerimónias preparatórias do sacrifício, enquanto outros se ocupam da imolação, [em segredo, aqui dentro, no recinto sagrado da deusa]. A noite passada trouxeme estranhos presságios, que agora conto aos céus, pois talvez assim sinta algum alívio. No sonho, pareceu-me que vivia em Argos, (45) longe desta terra, e que dormia ao lado de outras virgens. Então, a terra agitou-se num tremor e eu fugi. Lá fora, vi o entablamento do palácio desmoronar-se e o tecto inteiro desabar dos altos pilares, desfazendo-se em ruínas, por terra. (50) Da casa paterna, apenas uma coluna, de onde nascia um cabelo louro e de que se tinha apoderado uma voz humana, ou pelo menos assim me pareceu, ficou de pé. De acordo com a prática de matar estrangeiros, pus-me a aspergi-la, por entre lágrimas, como uma vítima que se prepara para morrer. (55) É assim que interpreto este sonho: Orestes está morto e foi nele que eu cumpri os rituais preparatórios do sacrifício, pois os filhos varóes são os pilares de uma casa. Além disso, morrem sempre aqueles que são atingidos pela minha água lustral. [E não posso relacionar o meu sonho com nenhum amigo, (60) pois Estrófio não tinha filhos quando eu fui dada em sacrifício.] $]^{9}$ Por isso, agora, ainda que ele esteja ausente, quero oferecer libaçóes ao meu irmão. Posso fazê-lo, com a ajuda das servas gregas que o rei me atribuiu. Mas, por que razão não apareceram elas ainda? (65) Vou entrar na morada sagrada da deusa, onde vivo.

\section{(Ifigénia entra no templo e Orestes e Pilades aparecem.)}

\section{Orestes}

Fica atento! Mantém-te vigilante, não vá aparecer alguém no caminho!

${ }^{9}$ Ifigénia refere-se ao tio, pai de Pílades, marido de Anaxíbia e cunhado de Agamémnon. 


\section{Píllades}

Estou atento! Mantenho-me alerta. Vou olhando em todas as direcçóes.

\section{Orestes}

Achas que é este o templo da deusa, Pílades, para onde navegaram as nossas naus (70) desde que saíram de Argos?

\section{Pílades}

Sim, acho que sim, Orestes! E não há razão para não concordares comigo.

\section{Orestes}

É então este o altar, de onde corre sangue helénico?

Pílades

Sim, e olha como está vermelho, por efeito do sangue...

\section{Orestes}

Estás a ver os troféus, pendurados nas cornijas?

\section{Pílades}

(75) Vejo! Juntamente com as cabeças de estrangeiros mortos. Mas temos de estar atentos a tudo o que nos cerca.

\section{(Pílades olha à sua volta.)}

\section{Orestes}

Ó Febo ${ }^{10}$ ! Que armadilha é esta a que me conduziste, através do teu oráculo? Expulsos da nossa terra, temos vindo a fugir das Erínias, (80) que se revezam para me perseguir, desde que honrei o sangue do meu pai, matando a minha mãe. Já percorri muitos caminhos sinuosos, depois de ter ido perguntar-te como podia terminar com esta loucura que me traz desvairado e com as penas [por que passei, às voltas pela Hélade]. Disseste-me que viesse aos confins da terra táurica, onde

${ }^{10}$ Apolo. 
Ártemis, tua irmã, tem altares, e que me apoderasse da estátua da deusa, a mesma que dizem que caiu do céu neste templo. Que a tomasse ou pela argúcia ou pela sorte e que, depois de ter corrido esse perigo, a levasse para o território dos Atenienses. (90) (Além disso, nada mais me revelaste). Apenas que, assim que cumprisse as tuas ordens, aliviaria as minhas penas. Obedecendo às tuas palavras, cheguei a esta terra desconhecida, inóspita. Pergunto-te, ó Pílades, (pois tens-me ajudado nestes trabalhos), (95) o que fazemos agora? Vês como é alta a parede que muralha o recinto? Devemos subir até ao templo? E como fazer para não sermos vistos? Partimos as barras de bronze com um bastáo? (100) †Mas não sabemos quais delas partir! $\dagger E$ se nos apanharem a abrir a porta e a prepararmo-nos para entrar, morremos. Portanto, antes que tal aconteça, fujamos para a nau que aqui nos trouxe.

\section{PílLAdes}

Fugir está fora de questão, não faz parte da nossa natureza. (105) Além disso, não há por que duvidar do oráculo do deus. Deixemos o templo e escondamo-nos longe da nau, numa gruta inundada pela água do mar sombrio. Não vá alguém ver a quilha do navio e informar o rei e acabarmos presos pela força. (110) Usemos todo o nosso engenho e assim que o olho da noite sombria espreitar, avançamos e trazemos do templo essa estátua polida. †Olha o espaço vazio que existe entre os tríglifos! Por ali pode passar uma pessoa! $\dagger$ De facto, os corajosos enfrentam os desafios, (115) enquanto os cobardes nada são, em lado nenhum. Não fizemos uma tão longa navegaçáo para agora voltarmos para trás, de regresso ao ponto de partida.

\section{Orestes}

Bem dito! Convenceste-me! Temos de ir para um lugar onde possamos esconder-nos para não sermos vistos. (120) 
Que não seja por minha culpa que o que foi decretado pelo deus deixe de se fazer. Há que ter coragem! Não há obstáculo que intimide quem é jovem.

(Orestes e Pilades saem. O coro de servas gregas entra a cantar. Ifigénia entra também e dirige-se ao coro.)

\section{IFIGÉNIA}

Calai-vos, vós que habitais as duas (125) rochas que se juntam no mar inóspito! ${ }^{11}$

\section{Coro}

Ó filha de Leto ${ }^{12}$ ! Ó Dictina das Montanhas ${ }^{13}$ ! Qual serva da chave sagrada ${ }^{14}$, conduzo os meus pés consagrados de virgem (130) para o teu pátio, para debaixo do tecto dourado do teu templo de belas portas. Eu, que deixei as torres e as muralhas da Hélade de belos cavalos (135), e a Europa de bosques frondosos, a sede da casa do meu pai. Eis-me aqui! O que há de novo? Que pensamento domina o teu espírito? Porque me trouxeste a este templo? Porque me trouxeste aqui, ó filha daquele que veio até às torres de Tróia, com o seu afamado remo, o dos mil navios, o dos dez mil guerreiros $^{15}$, †o ilustre Atrida†?

IFIGÉNIA

Ó servas, estou prostrada em tristes lamentos ${ }^{16}$,

11 Ifigénia refere-se às Planctas ou às Simplégades, rochedos que aparecem na Odisseia 12, 59-79, 201-231, e na Argonáutica 2, 316-340, de Apolónio de Rodes, e que, segundo a tradição, se entrechocavam com o objectivo de esmagar os navios que tentavam passar por entre eles.

${ }^{12}$ Mãe de Apolo e Ártemis.

${ }^{13}$ Dictina era uma divindade minóica associada ao monte Dicte, em Cidónia (Creta), e identificada com Ártemis. Cf. Heródoto 3, 59.

${ }^{14} \mathrm{O}$ coro refere-se à funçáo que a sacerdotisa de Ártemis tem, ao guardar a chave do templo. O mesmo acontecia em Bráuron, onde havia um importante santuário dedicado à deusa.

\footnotetext{
${ }^{15}$ Agamémnon.

${ }^{16} \mathrm{O}$ texto grego refere «trenos», cantos de lamento.
} 
(145) num canto sem música, num lamento sem lira ${ }^{17}$ ! Ai, numa compaixão fúnebre! As desgraças! Que desgraças se apoderaram de mim. Choro pela †vida $\dagger$ do meu irmão. †Que visão esta! † Que sonhos tive na noite cujas trevas agora se dissipam! Estou perdida! Estou perdida! A casa de meu pai já não existe! (155) Ai de mim! <Ai de mim!> A minha família desapareceu! Ai! Ai! Argos passou por tantos trabalhos! Ó destino, que me tiras o meu único irmão e o levas para o Hades! (160) É por ele que faço esta libação na face da terra, que verto a taça dos mortos e o líquido que vem das bezerras da montanha, (165) que te ofereço o vinho de Baco e o fruto do trabalho das abelhas de tom dourado, tudo o que proporciona a calma aos mortos ${ }^{18}$. Dá-me agora a urna de ouro para a libação de Hades. Ó rebento de Agamémnon, (170) que baixaste à terra. São estas as oferendas que te faço. Aceita-as, pois sobre o teu túmulo não posso depor o meu louro cabelo, as minhas lágrimas ${ }^{19}$. Na verdade, daí, de onde acreditam que jazo degolada, fui enviada para muito longe (175) da tua, e da minha, pátria. Que miserável sou!

\section{Coro}

Entoo-te cânticos responsórios e (180) hinos asiáticos que são como ruídos bárbaros, senhora. Aos mortos a Musa canta lamentos fúnebres ${ }^{20} \mathrm{e}$ hinos a Hades, (185) bem

${ }^{17}$ A referência a um canto "sem música» ou, literalmente, "que não é de boa musa" e "sem lira», pretende mostrar a ausência da harmonia, da alegria e da serenidade que a música da lira proporciona a quem a ouve.

${ }_{18}$ Neste passo encontramos o ritual que os Gregos dedicavam aos mortos.

19 A oferenda de anéis de cabelo constituía uma prática ritual dos Gregos em relação aos mortos. A referência à mesma nesta tragédia encontra eco nos actos de Electra e Orestes, irmáos de Ifigénia, em outros textos, como Coéforas de Ésquilo.

${ }^{20}$ Trenos. 
diferentes dos péans ${ }^{21}$. Ai de mim! Ai da casa dos Atridas! A luz do ceptro extingue-se, ai de mim, ai da casa do meu pai. †Outrora, o poder pertencia aos reis de Argos, (190) mas desgraças sucederam-se sem cessar a outras desgraças $\dagger<>$ e os cavalos alados de Pélops deram a volta, alterando a rota da sagrada †luz do olho de Hélio ${ }^{22} \uparrow$. (195) †Mais, $†$ sobre o tecto do cordeiro de ouro caiu a desgraça, †a morte sobre a morte, a dor sobre a dor $\dagger^{23}$. O castigo desabou sobre a casa dos Tantálidas já mortos, (200) e a divindade precipitou sobre ti o que náo procuraste.

\section{IFIGÉNIA}

Desde o início que o destino me foi contrário, <> (205) desde a barriga da minha mãe, desde aquela noite... No princípio, as deusas Meras, senhoras do nascimento ${ }^{24}$, asfixiaram fortemente a minha infância. (210) Fui do tálamo materno, da infeliz filha de Leda ${ }^{25}$, a primogénita. Vi-me oferecida como vítima num sacrifício triste, pelo ultraje do meu pai. $\nmid$ Vim ao mundo e me criei para servir de vítima sacrificial†. Para as areias de Áulis me levaram num carro puxado por cavalos, (215) como noiva, ai de mim, como noiva que nunca viria a casar-se com o filho da Nereide ${ }^{26}$ ! E agora, qual hóspede do mar inóspito, habito uma casa onde a comida não abunda, solteira, sem filhos, (220) sem pátria, sem ami-

${ }^{21}$ Hinos em honra de Apolo.

${ }^{22}$ Nova referência ao mito de Pélops, antepassado dos Atridas. Ver nota 3. Este passo funciona como metáfora da alteraçáo dos acontecimentos.

${ }^{23}$ Alusão ao cordeiro do velo de ouro, que foi encontrado por Atreu, avô de Ifigénia. Aquele tinha prometido sacrificar a Ártemis o melhor produto do seu rebanho, mas acabou por reservar para si o referido animal, ofendendo a deusa e contribuindo para a maldição dos Atridas. Sobre este mito, ver Séneca, Tiestes 222-244.

${ }^{24}$ As Meras são as personificações do destino de cada ser humano.

${ }^{25}$ Clitemnestra.

${ }^{26}$ Aquiles e sua mãe, Tétis. 
gos, (208) como aquela cujo noivado a apartou dos Helenos. (221) Não canto a Hera, senhora de Argos, nem no tear, que tão bem soa, bordo com a lançadeira a imagem da ateniense Palas e dos Titãs ${ }^{27}$. Em vez disso, infeliz, (225) †derramo sobre o altar, com golpes sanguinários e impróprios para o som da lira, o sangue de estrangeiros $\dagger$, que lançam gritos plangentes, como plangentes são as suas lágrimas... Mas esqueçamo-los. Agora, choro o meu irmão, (230) morto em Argos, a quem deixei ainda menino de leite, um bebé, um rebento, criança que ainda era nos braços da máe, que o apertavam contra o peito: (235) Orestes, o senhor do ceptro de Argos.

\section{(Aproxima-se um boieiro.)}

\section{Coro}

Eis que, vindo da costa, chega um boieiro, que te traz novidades.

\section{BoIEIRO}

Filha de Agamémnon e de Clitemnestra, escuta as novas que tenho para te dar.

IFIGÉNIA

(240) $\mathrm{O}$ que perturba as minhas palavras neste momento?

\section{BoIEIRO}

Chegaram a esta terra, depois de terem fugido num navio às sombrias Simplégades, dois jovens, vítimas para um sacrifício querido à deusa Ártemis. (245) Apressa-te a purificar a mãos e a tratar das primícias.

${ }^{27}$ Referência às Panateneias, festas em honra de Atena, em que as jovens casadoiras da aristocracia ateniense apresentavam à deusa um peplo novo, decorado com cenas da batalha mítica, em que a deusa Atena ajudou Zeus a derrotar os Gigantes rebeldes, mas que aqui são referidos como Titás. A tradição, porém, dizia que a Titanomaquia ocorrera antes do nascimento de Atena, como se pode confirmar em Hesíodo, Teogonia 629-900. 


\section{IFIGÉNIA}

De que país são? De que terra aparentam os estrangeiros ser?

\section{BOIEIRo}

São Helenos. É tudo o que sei.

IFIGÉNIA

Depois de teres ouvido o nome dos estrangeiros, não sabes dizer-mo?

BOIEIRO

Um chamava ao outro Pílades.

IFIGÉNIA

(250) E ele mesmo como se chamava, esse estrangeiro?

BOIEIro

Ninguém o sabe! Não o ouvimos.

IFIGÉNIA

Como foi que vocês souberam deles, os encontraram e os capturaram?

\section{BOIEIRO}

Foi no ponto mais alto do promontório, no estreito inóspito.

\section{IFIGÉNIA}

E o que tem o mar em comum com os boieiros?

\section{BOIEIRO}

(255) Fomos lá para lavar os bois na água do mar.

IFIGÉNIA

Chega cá e diz-me como e de que modo os apanharam. Quero sabê-lo. [Pois há muito tempo que o altar da deusa não é inundado com sangue heleno.] 


\section{BoIEIRO}

(260) Assim que encaminhámos os bois, que se alimentam nos bosques, para o mar que corre por entre as Simplégades $^{28}$, vimos uma gruta, escavada pela contínua agitação das vagas. Era um abrigo para os pescadores da púrpura. (265) Um dos nossos boieiros viu aí dois rapazes. Voltou então para trás, em bicos de pés, e disse-nos: "Estais a ver? São divindades, aqueles que ali estão sentados!» Outro dos nossos, que é temente aos deuses, ergueu as mãos e, ao vê-los, começou a orar: "Ó filho da marinha Leucótea ${ }^{29}$, protector dos navios, (270) ó soberano Palémon ${ }^{30}$, sê-nos propício. São talvez os Dioscuros ali sentados junto ao mar, ou os belos filhos de Nereu, de quem nasceu o nobre coro das cinquenta Nereides ${ }^{31}$.» (275) Um outro, que era insensato e um ousado sabotador das leis, riu-se da prece e disse que eram marinheiros naufragados, que por ouvirem dizer que aqui se oferecem os estrangeiros em sacrifício se esconderam no fundo da falésia, com medo da lei. A maioria de nós pensou que ele tinha razão, pelo que decidimos apanhá-los para serem oferecidos à deusa, (280) tal como é costume neste país. Nisto, um dos estrangeiros sai da gruta e abana a cabeça, soltando gemidos, ao mesmo tempo que os braços lhe tremiam. Num acesso de loucura, gritava †como um caçador †: «Estás a vê-la, Pílades? (285) Não vês aqui a

${ }^{28}$ Ver nota 11.

${ }^{29}$ Deusa marinha, também conhecida como Ino, era filha de Cadmo e irmá de Sémele. Ainda enquanto Ino, antes de se transformar numa divindade, foi enlouquecida por Hera e por isso lançou ao mar o próprio filho. As divindades marinhas apiedaram-se da mãe e do filho e divinizaram ambos.

${ }^{30}$ Filho de Leucótea.

${ }^{31}$ As Nereides eram divindades marinhas, filhas de Nereu e de Dóris, uma das filhas de Oceano. A tradição grega tinha ainda Nerites, herói de grande beleza, como filho de Nereu. Ver Eliano, Da natureza dos animais $14,28$. 
serpente de Hades, que me quer matar? Tem a boca cheia de terríveis víboras! E esta aqui ao lado? Esta que, das vestes, sopra fogo e agita as asas homicidas, carregando a minha mãe nos braços, como se fosse de pedra, (290) para a deixar cair sobre mim! Ai infeliz! Vai matar-me! Para onde posso fugir?» Quem ali estava não via aquelas figuras, mas ele †entendia $\dagger$ o balido dos bezerros e o latido dos cães $\uparrow$ como os barulhos $\dagger$ que as Erínias ${ }^{32}$ imitam e soltam. (295) Ali ficámos, juntos, como mortos, sentados em silêncio. Foi então que ele desembainhou a espada e avançou, num ímpeto, para o meio das bezerras, qual leão. Com o ferro, golpeava-lhes os flancos, feria-lhes as costelas, convicto de assim afastar as deusas Erínias, (300) até que o sangue floresceu sobre a salmoura do mar. Então, ao vermos que, devastada, toda a manada caía, armámo-nos até aos dentes, soprámos nas conchas e reunimos a gente do país, simples boieiros que éramos, dispostos a lutar contra estrangeiros jovens e robustos. (305) Assim, em pouco tempo, recrutámos muitos aliados. Já livre do acesso de terror e de loucura, o estrangeiro caiu no chão, com a barba coberta de espuma. Era esse o momento conveniente: ao vê-lo assim caído, todos os homens agarraram em pedras, lançaram-nas sobre ele, a tentarem feri-lo. (310) O companheiro limpavalhe a espuma e procurava protegê-lo. Com a túnica de fino tecido entrançado, cobria-o, atento a prevenir os arremessos que vinham de longe, como quem, qual benfeitor, cuidava de um amigo. Ao recuperar a razão, (315) o estrangeiro reerguese e dá-se conta da vaga de inimigos que sobre ele investia. Percebe a desgraça iminente. Em desespero, gritou. Mas nós não parámos de arremessar pedras, atingindo-os, ora de um lado ora do outro. (320) Foi então que ouvimos a sua terrível exortação: "Vamos morrer, Pílades! Mas então morramos

${ }^{32}$ Divindades primordiais cuja função é vingar os crimes. 
em beleza! Desembainha a espada e segue-me!» Ao vermos brandir as espadas nas mãos dos inimigos, o vale rochoso foi invadido pela nossa fuga. Mas se um fugia, (325) os outros atingiam-no com arremessos. E se estes eram repelidos, era a vez dos que retrocediam lhes atirarem pedras. Mas o incrível foi o número incontável de golpes que não conseguiu atingir as vítimas da deusa. A custo, lá os dominámos, (330) não graças à nossa coragem, mas ao facto de os termos cercado, de lhes termos atirado pedras e de os termos desarmado. Caíram então por terra, de joelhos, exaustos. Levámo-los à presença do senhor da região. Este, ao vê-los, rapidamente os encaminhou para ti, (335) para que os purificasses e sacrificasses. Ó donzela, faz um voto para que te apareçam vítimas como estas, estrangeiros. Se os matares, a Hélade expiará a tua morte, e pagará o preço justo pelo teu sacrifício em Áulis.

\section{Coro}

(340) Incrível o que disseste desse demente, quem quer que seja esse heleno, que veio da sua terra até este mar inóspito.

\section{IFIGÉNIA}

Pois bem, vai e traz-me os estrangeiros, que nós aqui tratamos do ritual. ( $O$ boieiro sai.) Ó infeliz coração! Até agora foste sempre calmo e misericordioso (345) para com os estrangeiros, medindo pelas tuas as lágrimas dos teus conterrâneos, de cada vez que um heleno te caía nas mãos. Mas desta vez, que por estes sonhos que me inundam de ira [acredito que Orestes já não vê o Sol] (350), encontramme hostil, quem quer que sejam os que aqui chegaram. [E percebo agora, minhas amigas, que é verdade que os desafortunados não têm bons sentimentos para com os mais afortunados, e que os não poupam.] Mas nunca aqui chegou 
o sopro de Zeus ou uma nau que, (355) através das rochas Simplégades ${ }^{33}$, trouxesse Helena, aquela que me perdeu, e Menelau, para que me vingasse; igualaria então esta terra a Áulis, onde os Dánaos me fizeram o mesmo que a uma vitela: entregaram-me para a matança, sendo sacerdote o pai que me gerou. (360) Ai de mim! (Não quero lembrar-me das desgraças que então vivi!) Quantas vezes aproximei as minhas máos da face e dos joelhos daquele que me fez vir ao mundo?34 E agarrada a ele dizia: "Ó pai, dás-me em casamento num matrimónio vergonhoso! Enquanto me matas, a minha mãe e (365) as Argivas entoam cânticos a Himeneu $^{35}$ e todo o palácio se enche com o som das flautas. E eu morro às tuas mãos. Afinal era Hades, e não o filho de Peleu, o Aquiles que me destinavas para marido. (370) Num carro, touxeste-me ao engano para uma boda de sangue. Já com um véu fino a cobrir-me os olhos, não peguei no meu irmão, que agora está morto, nem beijei a minha irmã, por pudor, (375) pois ia para o palácio de Peleu. Não fiz grandes despedidas, já que voltava a Argos. Ó desgraçado Orestes! Se estás morto, que tipo de benefícios ou de invejas do teu pai te vitimou? (380) Censuro os artifícios desta deusa. Se um mortal contacta com o sangue derramado ou se toca com as máos numa parturiente ou num cadáver, ela expulsa-o dos altares, por o ter como impuro. No entanto, agrada-se com sacrifícios humanos. (385) Leto, a mulher de Zeus, não pode ter trazido ao mundo tamanha insensatez. Eu não acredito no banquete que Tântalo terá oferecido aos deuses, que se teriam deliciado ao comer-lhe o filho. Do mesmo modo, penso também que é esta gente a homicida, embora atribua à

\footnotetext{
${ }^{33}$ Ver nota 11.

${ }^{34}$ Ifigénia descreve a postura do suplicante.

${ }^{35}$ Divindade que conduz o cortejo nupcial.
} 
deusa a sua maldade. (390) Não posso acreditar na crueldade dos deuses

\section{Coro}

\section{Estrofe 1}

Sombria, sombria é a confluência dos mares, onde o moscardo que †voou de Argos † atravessou o mar inóspito < >, (395) trocando a Europa pela terra da Ásia ${ }^{36}$. (400) Quem são então estes que abandonaram o Eurotas ${ }^{37}$ de abundantes águas e verdejantes canaviais, ou as correntes sagradas do Dirce $^{38}$, que andaram, andaram até chegarem a esta terra hostil, onde o sangue humano ensopa os altares e o pórtico sagrado (405) da filha de Zeus?

\section{Antistrofe 1}

Quem são estes que $†$ navegaram $\dagger$ ao som do duplo bater dos remos de abeto, †sobre as ondas do mar†, (410) $<$ no $>$ seu transporte naval, com a brisa a soprar-lhe as velas, em demanda de riquezas que aumentem os seus palácios? A tão amada esperança, †que nasce das misérias dos mortais $\dagger$,

${ }^{36}$ Numa referência ao Bósforo, o coro relembra a história de Io, jovem sacerdotisa de Hera. Zeus apaixonara-se por Io, tendo-se unido a ela. Hera desconfiou do sucedido e Zeus viu-se obrigado a transformar Io numa vitela branca, para escapar à ira da mulher. Hera, porém, exigiu a Zeus que ele lhe oferecesse o animal e acabou por confiá-lo à guarda de Argo, criatura que contava com cem olhos. Io vagueou por diversas regióes do mundo até que Zeus se apiedou dela e encarregou Hermes de a arrebatar ao seu guarda. Hermes adormeceu alguns dos olhos de Argo, enquanto os restantes dormiam já de sono natural. O filho de Zeus matou entáo o guarda. Mas a morte deste náo livrou Io dos seus tormentos, pois Hera enviou entáo um moscardo para atormentar a jovem metamorfoseada. $\mathrm{O}$ insecto agarrou-se-lhe ao flanco e Io, desvairada, correu por toda a Grécia, chegando mesmo a atravessar o mar no estreito que separa a Europa da Ásia, dando-lhe assim o nome de «Bósforo» ou «Passagem da Vaca». Io acabou por se instalar no Egipto, onde deu à luz um filho de Zeus, Épafo. Sobre este mito ver Ésquilo, Suplicantes 41ss.; Ovídio, Metamorfoses 1, 583-746.

\footnotetext{
${ }^{37}$ Rio de Esparta.

${ }^{38}$ Rio de Tebas.
} 
(415) é insaciável para os homens que carregam o peso das riquezas e que erram sobre as vagas do mar, atravessando cidades bárbaras, numa expectativa comum. (420) A uns, a ideia de riqueza sai frustrada, enquanto para outros, ela resulta em cheio.

Estrofe 2

De que modo atravessaram eles as rochas que se entrechocam ${ }^{39}$ ? Como passaram as costas insones dos filhos de Fineu ${ }^{40}$ ? Junto à costa, como correram sobre o rumor das vagas de Anfitrite ${ }^{41}$, (425) onde, em círculo, as cinquenta filhas de Nereu ${ }^{42}<>$ entoam coros (430) como velas enfunadas pelo vento, enquanto o timoneiro repousa na proa, tocando siringe às húmidas brisas ou aos sopros de Zéfiro ${ }^{43}$, na terra de muitas aves, (435) a costa branca, tal qual um belo estádio no mar inóspito para as corridas de Aquiles?

\section{Antistrofe 2}

Queiram os deuses que, em resposta às súplicas da minha ama, Helena, (440) a filha querida de Leda, de regresso da cidade de Tróia chegue até aqui; com os cabelos coroados de sangue, há-de morrer às mãos da minha senhora, degolada, (445) pagando o que fez com igual preço. Que recebamos a mais agradável das notícias: da terra da Hélade chegou um marinheiro para acabar com as agruras da minha desgraçada escravidão. (450) Que eu estivesse, <pois>, em casa, nem que fosse só em sonhos, na cidade de meu pai, dormindo o sono dos justos, graça da $\nmid$ felicidade $\dagger$ a todos consentida.

\section{${ }^{39}$ Ver nota 11.}

${ }^{40}$ Rei da Trácia, cego e com poderes divinatórios, que era atormentado pelas Harpias. $\mathrm{O}$ coro refere-se às costas da Trácia, do Bósforo ao promontório de Tínia.

${ }^{41}$ Nereide amada por Posídon.

${ }^{42}$ Divindade marinha.

${ }^{43} \mathrm{O}$ vento do Ocidente, bom para a navegação da Grécia para a Ásia. 
(455) Mas eis que se aproximam os dois homens, de mãos atadas, quais vítimas sacrificiais dedicadas à deusa. Calai-vos, amigas, pois as primícias dos Helenos continuam a avançar e estão já perto do templo. (460) Não era mentira o que o boieiro nos anunciou. Ó senhora, se assim te agradam as oferendas que esta cidade te faz, então, †ao te entregarmos os Helenos $†$, aceita com apreço a que fazemos (465) ainda que a nossa lei a não sancione como sagrada!

(Orestes e Pilades entram, presos e escoltados por Tauros.)

\section{IFIGÉNIA}

Pois bem. Em primeiro lugar, tratarei de assegurar que os rituais da deusa corram bem. Desatai as mãos dos estrangeiros, pois sendo sagrados não devem estar presos. (470) Ide dentro do templo e preparai o necessário que a tradição exige para esta oferenda. Ah! Quem é a mãe que um dia vos deu à luz? E o pai? E a irmã, se é que a tendes, que vai perder dois irmãos? (475) Quem sabe a quem caberá uma sorte assim? Pois tudo o que pertence aos deuses se arrasta pelo desconhecido e ninguém conhece o †mal† que lhe está reservado, visto que o destino apenas nos conduz à ignorância. De onde vindes, ó estrangeiros desgraçados? (480) Foi longa, a navegação para esta terra, mas agora ficareis lá em baixo, longe de casa, por muito tempo. Para sempre.

\section{Orestes}

Porque te lamentas dessa maneira e porque te preocupam as desgraças que nos estáo para acontecer, quem quer que tu sejas, ó mulher? Na verdade, não creio que seja sensato que (485) quem está prestes a morrer queira vencer o medo da morte com compaixão e que alguém que, estando tão perto do Hades, se lamente, quando não há esperança de salvação. De um mal nascem dois: revela-se a insanidade 
e acaba-se por morrer à mesma. Há que ceder à sorte. (490) Não te lamentes por nós, pois conhecemos e sabemos quais as oferendas deste lugar.

IFIGÉNIA

Qual dos dois responde aqui pelo nome de Pílades? É isso o que quero saber em primeiro lugar.

(Orestes aponta Pílades.)

Orestes

Este, se te dá algum prazer sabê-lo.

IFIGÉNIA

(495) De que pátria helénica és cidadão?

Orestes

E para que queres saber tudo isso, mulher?

IFIGÉNIA

Sois os dois irmãos, filhos de uma mesma mãe?

Orestes

Somos irmãos mas por laços de amizade, não por sangue, mulher.

IFIGÉNIA

E a ti? Que nome te pôs o pai que te gerou?

Orestes

(500) Em justiça, deveria ter-me chamado Desgraçado.

IFIGÉNIA

Não é isso que te estou a perguntar. Se assim é, tens de culpar a sorte.

Orestes

Se morrermos anónimos, ninguém se rirá de nós.

IFIGÉNIA

Porque vês isto com malícia? Porque és assim tão prudente? 


\section{Orestes}

Será o meu corpo que oferecerás em sacrifício aos deuses, não o meu nome.

IFIGÉNIA

(505) E também não me dirás a que cidade pertences?

\section{Orestes}

Procuras o que não interessa, pois vamos morrer.

IFIGÉNIA

O que te impede de me fazer a vontade?

ORESTES

Orgulho-me de ter Argos por pátria.

IFIGÉNIA

Pelos deuses, estrangeiro, é verdade que nasceste lá?

Orestes

(510) Sou de Micenas, a outrora opulenta!

\section{IFIGÉNIA}

(515) Pois és muito bem-vindo, se vens de Argos.

\section{Orestes}

(516) Não para mim. Se o sou para ti, cabe-te decidi-lo.

IFIGÉNIA

(511) Vens fugido da tua pátria? A que sorte foges tu?

\section{Orestes}

De certo modo, fujo tanto por minha vontade como contra ela.

\section{IFIGÉNIA}

Será que me vais dizer alguma coisa do que quero saber?

\section{Orestes}

(514) Será apenas um acrescento à minha desgraça. 
IFIGÉNIA

(517) Também conheces Tróia, aquela de que se fala por todo o lado?

Orestes

Pagaria para que nunca dela tivesse ouvido falar, nem sequer em sonhos.

IFIGÉNIA

Dizem que já não existe, que desapareceu a golpes de lança.

Orestes

(520) Assim é! Ouviste bem.

IFIGÉNIA

E Helena regressou à casa de Menelau?

Orestes

Regressou, e com ela a desgraça a um dos meus.

IFIGÉNIA

E onde está ele? Há muito também que tem uma dívida em aberto para comigo, pelo mal que me fez.

Orestes

Vive em Esparta, com o marido de outrora.

IFIGÉNIA

(525) Ó odiada pelos Helenos e não apenas por mim!

\section{Orestes}

Também eu beneficiei do casamento dela ${ }^{44}$.

IFIGÉNIA

E o regresso dos Aqueus a casa, foi como se conta?

\section{Orestes}

Interrogas-me com uma única pergunta, mas nada te escapa!

\footnotetext{
${ }^{44}$ Orestes recorre à ironia.
} 
IFIGÉNIA

Quero que me digas tudo antes de morreres.

Orestes

(530) Pergunta-me o que quiseres. Responder-te-ei.

IFIGÉNIA

$\mathrm{O}$ adivinho Calcas regressou de Tróia?

Orestes

Morreu em Micenas, segundo se diz.

IFIGÉNIA

Ó senhora, ainda bem! E o que é feito do filho de Laertes ${ }^{45}$ ?

Orestes

Ainda não regressou a casa, mas está vivo, ao que oiço dizer.

IFIGÉNIA

(535) Que morra, sem regressar!

\section{Orestes}

Não há por que maldizê-lo, pois à volta dele tudo adoece.

IFIGÉNIA

E o filho da nereide Tétis ${ }^{46}$, ainda vive?

\section{Orestes}

Não. Foi em vão que se casou em Áulis.

\section{IFIGÉNIA}

E à traição, como sabem os que se viram envolvidos no assunto.

\footnotetext{
45 Ulisses.

${ }^{46}$ Aquiles.
} 
Orestes

(540) Mas quem és tu? Estás bem informada acerca da Hélade.

IFIGÉNIA

Eu sou de lá! Era ainda uma criança quando me perderam.

\section{Orestes}

Então está certo que queiras saber o que lá se passa, mulher.

IFIGÉNIA

E o que é feito do comandante, a quem chamam afortunado?

Orestes

Quem? Aquele que eu conheço não é de todo afortunado.

IFIGÉNIA non!

(545) Falo do filho de Atreu, do soberano Agamém-

\section{Orestes}

Nada sei! Pára com essa conversa, mulher!

IFIGÉNIA

Não, pelos deuses! Fala, satisfaz a minha curiosidade, estrangeiro!

\section{Orestes}

O desgraçado morreu e levou outros à destruição.

IFIGÉNIA

Morreu? Em que circunstâncias? Desgraçada de mim!

Orestes

(550) Porque o lamentas? Por acaso era-te chegado? 
IFIGÉNIA

Lamento-o pela prosperidade de outrora.

Orestes

Morreu de uma forma horrível, degolado por uma mulher.

IFIGÉNIA

Digno de dó é tanto quem o matou como quem morreu.

Orestes

Ficamos por aqui, não me perguntes mais nada.

IFIGÉNIA

(555) Só mais uma questão: a mulher desse infeliz ainda está viva?

\section{Orestes}

Não! Matou-a o filho que deu à luz.

IFIGÉNIA

Ó casa em turbilhão! O que pretendeu ele com esse acto?

\section{Orestes}

Vingar-se dela, pela morte do pai.

IFIGÉNIA justiça!

Ai! Agiu bem, embora praticasse um mau acto de

\section{Orestes}

(560) Mas que, ainda que justo, não tem a aprovação dos deuses.

\section{IFIGÉNIA}

E Agamémnon deixou algum outro filho em casa?

\section{Orestes}

Deixou apenas uma, Electra, virgem ainda. 
IFIGÉNIA

E a filha que foi sacrificada? Há algum rumor?

\section{Orestes}

Nada. Apenas que morreu, que já não vê a luz do dia.

IFIGÉNIA

(565) Infeliz, ela e o pai que a matou.

\section{Orestes}

Morta pela má graça de uma mulher desgraçada.

IFIGÉNIA

E o filho do pai morto? Está em Argos?

\section{Orestes}

O infeliz está em todos os lados e em nenhum, ao mesmo tempo.

\section{IFIGÉNIA}

Sonhos enganadores adeus, que de nada me valeis.

\section{Orestes}

(570) Nem as divindades, a quem chamam sábias, são mais verdadeiras do que os sonhos fugazes. Há muita perturbação entre os deuses e entre os mortais, †mas uma coisa é realmente dolorosa†: que alguém, sem ser insensato mas por fazer fé nas palavras de adivinhos, se veja perdido (575) - porque está perdido aos olhos de quem sabe.

\section{Coro}

Ai! Ai! E nós? E os nossos pais? Ainda vivem? Ou já não vivem? Quem no-lo diz?

\section{(Ifigénia continua a dirigir-se aos prisioneiros.)}

\section{IFIGÉNIA}

Escutai! Estive a pensar e tive uma ideia que vos poderá ajudar, estrangeiros, (580) e ao mesmo tempo ajudar-me, 
a mim. †Chega-se† a um entendimento quando algo é bom para todos. Se, por acaso, eu te salvasse, estarias disposto a ir a Argos e a levar uma mensagem minha a uns entes-queridos que tenho lá? Trata-se de uma tabuinha que um prisioneiro me escreveu, com pena de mim, (585) certo de que não era a minha mão que o matava, mas que morria por causa do costume, $\nmid$ da deusa que o tem como justo $\dagger$. Ainda nunca houve ninguém que se salvasse, regressasse a Argos e levasse $<$ a $>$ minha mensagem (590) a um dos meus parentes. Mas tu, que não me pareces hostil e conheces Micenas e quem eu amo, podes salvar-te a troco de um pagamento de que não te envergonharás. Aceita a tua salvação em troca de umas leves letras. E que apenas o teu amigo (595) fique e seja oferecido à deusa ${ }^{47}$, uma vez que a cidade assim o exige.

\section{Orestes}

Tens razão, estrangeira, excepto numa coisa: a morte dele é para mim um grande fardo. (600) Pois sou eu o portador de desgraça e ele apenas navega comigo para partilhar os meus tormentos. Não é, pois, justo que seja eu a ganhar o teu favor em troca da morte dele e desse modo me livre da desgraça. Mas faremos assim: dá-lhe essa tabuinha. Ele levá-la-á para Argos e tudo correrá bem. E que eu seja morto por quem me quiser matar. Nada é mais vergonhoso do que alguém (605) salvar-se a si mesmo, lançando um amigo na desgraça. E este é um amigo a quem desejo que veja a luz do dia tanto como a mim próprio.

\section{IFIGÉNIA}

Nobre decisão! Quão distintas são as raízes de que nasceste (610) e quão verdadeiro amigo és dos teus amigos! Fosse assim o parente que me resta! Pois a mim, estrangeiros,

${ }^{47}$ Ifigénia refere-se a Pílades. 
ainda me resta um irmão, ainda que não saiba dele. Uma vez que queres assim, enviamo-lo então a ele com a tabuinha. Serás tu a morrer, (615) já que tanto o desejas.

\section{Orestes}

Quem me oferecerá em sacrifício? Quem suportará esse horror?

IFIGÉNIA

Eu! Pois tenho a função de apaziguar a deusa!

\section{Orestes}

Não é uma tarefa feliz ou invejável, rapariga!

IFIGÉNIA

(620) Mas vejo-me nesta necessidade e tenho de zelar por ela.

\section{Orestes}

Sendo tu uma mulher, feres a homens com a espada?

IFIGÉNIA

Não! Eu apenas lustrarei o teu cabelo.

\section{Orestes}

E quem é o carrasco? Se é que devo perguntar...

\section{IFIGÉNIA}

Os que se ocupam disso estão dentro desta casa.

\section{Orestes}

(625) Que tipo de funeral me será feito depois de morrer?

\section{IFIGÉNIA}

Na pedra, há uma ampla abertura e lá dentro estará o fogo sagrado ${ }^{48}$.

${ }^{48}$ Cf. Diodoro Sículo 20, 14, em que se lê acerca das práticas funerárias dos Cartagineses, semelhantes às descritas por Eurípides neste passo. 


\section{Orestes}

Ai! Como me amortalhariam as mãos da minha irmã?

IFIGÉNIA

Vã súplica fazes, ó infeliz, quem quer que sejas! Ela vive longe desta terra bárbara. Visto que és argivo, porém, (630) não deixarei de te fazer esse favor, dentro das minhas possibilidades. Muitos serão os adornos que porei sobre o teu sepulcro, azeite dourado †consumirá $\dagger$ o teu corpo e sobre a tua pira lançarei o suco das (635) abelhas amarelas da montanha, que brilha ao escorrer por entre as flores. Vou então buscar a tabuinha ao templo da deusa. Trata, portanto, de não me hostilizar. Servos, vigiai-os, sem as ataduras! É de forma inesperada que envio ao meu familiar querido de Argos, (640) àquele a quem mais amo, a tabuinha com uma mensagem, a anunciar que estáo vivos aqueles que ele acredita mortos. Estas são palavras que decerto lhe darão muito prazer.

Pilades.)

(Ifigénia entra no templo. O coro dirige-se a Orestes e a

\section{Coro}

A ti eu lamento, tu que serás a razão (645) das gotas sangrentas na água lustral.

\section{Orestes}

Não há por que ter compaixão! Em vez disso, alegraivos, estrangeiras!

\section{Coro}

A ti, jovem, te bendizemos pela boa sorte que te coube, pois voltarás a pôr os pés na tua pátria.

\section{Pílades}

Não é invejável que quem é amigo (650) veja morrer os seus amigos. 


\section{Coro}

Ó cruel missão! Ai! Ai! Estais <os dois> perdidos! Ai! Ai! $†$ E qual dos dois o estará mais? $\dagger$ (655) Na verdade, o meu espírito debate-se entre dois contrários: por quem devo soltar o meu primeiro lamento, por ti ou por ti?

\section{Orestes}

Pensas dos deuses o mesmo que eu, Pílades?

Pílades

Não sei. Não sei o que responder à tua pergunta.

\section{Orestes}

(660) Quem é esta rapariga? Foi em grego que fez o seu interrogatório acerca dos nossos sofrimentos e de Ílio ${ }^{49}$, do regresso dos Aqueus a casa, e de Calcas, o que entendia os sinais das aves, e do nome de Aquiles. E como lamentou o infeliz Agamémnon e me perguntou (665) pela mulher e pelos filhos dele. A estrangeira é de lá, tem ascendência argiva. De outro modo, se ali não tivesse nenhum interesse, não enviaria a tabuinha nem quereria saber se em Argos está tudo bem.

\section{Pílades}

Tiraste-me as palavras da boca. Antecipaste o que eu tinha a dizer, excepto numa coisa: (670) todos os que as presenciaram conhecem as infelicidades por que os reis passaram. No entanto, uma outra ideia me passou pela cabeça...

\section{ORESTES}

Qual? Ficará mais clara se a partilhares.

\footnotetext{
${ }^{49}$ Outra designação para Tróia e sua região.
} 


\section{PÍlLADES}

É vergonhoso que eu veja a luz do dia e que tu morras. (675) Naveguei contigo, morrerei contigo. Pois, caso contrário, serei acusado de cobardia e maldade, em Argos e na Fócida, terra de muitos vales. À maioria, pois a maioria é perversa, parecerá que me salvei, entregando-te, e que só por isso estou em casa. Ou que (680) te assassinei e tramei a tua destruição, juntamente com a destruição da tua casa, para ficar com a tua realeza, casando com a herdeira, a tua irmá. $\mathrm{Na}$ verdade, é disso que tenho medo e que me envergonha. Nada poderá impedir que morra contigo, (685) que seja sacrificado contigo e que o meu corpo seja cremado, pois sou teu amigo e temo a censura alheia.

\section{Orestes}

Náo digas isso! Tenho de suportar os meus sofrimentos. Mas se me é possível ficar por uma só dor, não suportarei duas. Aquilo a que chamas doloroso e censurável também o será para mim, (690) caso morras por minha culpa, por partilhares as minhas desgraças. Para mim, não será mau de todo perder a vida, sofrendo o que estou a sofrer por determinação divina. Tu, porém, és um felizardo, pois tens um tecto limpo e não contaminado, enquanto eu sou um maldito e um infeliz. (695) Se te salvares, e se da irmá que te dei como esposa tiveres filhos, o meu nome viverá e a casa do meu pai não se extinguirá sem descendência. Por isso, vai, vive e habita a casa do meu pai. (700) E promete pela tua mão direita que quando chegares à Hélade e à hípica Argos me darás um túmulo e me erguerás um monumento. A minha irmã oferecerá então ao sepulcro lágrimas e cabelos ${ }^{50}$. Conta-lhe como morri às mãos de uma mulher argiva, (705)

${ }^{50}$ A já referida prática funerária grega de oferecer madeixas de cabelo aos mortos e às sepulturas. 
purificado para o sacrifício. E nunca traias a minha irmá, ainda que vejas a desolação e o abandono a que está sujeita a casa do meu pai. Adeus! Tenho-te como o mais amado dos meus amigos, ó meu parceiro de caça e meu companheiro desde a infância, tu que suportaste (710) o grande fardo dos meus males. Febo, apesar de adivinho, enganou-nos. Usando de artifícios, afastou-nos o mais possível da Hélade, envergonhado dos oráculos que antes me enviou. Entreguei-me todo a ele, confiei nas suas palavras e assassinei a minha mãe. (715) Agora, em troca, sou eu próprio que morro.

\section{Pílades}

Terás o teu túmulo e não atraiçoarei o leito da tua irmã, ó infeliz! Apesar de morto, a minha amizade será mais profunda do que quando vivias. No entanto, o oráculo do deus ainda não te destruiu, (720) por muito perto que estejas da morte. Mas o certo, certo mesmo, é que quando se dá uma grande desgraça, a sorte traz, em determinadas ocasióes, grandes mudanças.

\section{Orestes}

Silêncio! As palavras de Febo não me ajudaram. Esta mulher vem a sair do templo.

\section{(Ifigénia sai do templo e traz as tabuinhas.)}

\section{IFIGÉNIA}

(725) Vós ${ }^{51}$, ide para dentro e preparai o que é necessário ao sacrifício. Aqui está, estrangeiros, a mensagem, em várias tabuinhas. Escutai o que quero que façais com elas, pois nenhum homem é o mesmo quando está em apuros e quando se livra do medo e reconquista a coragem. Temo que aquele que desta terra regressar a casa, para levar estas

${ }^{51}$ Ifigénia dirige-se em primeiro lugar às servas. 
tabuinhas a Argos, acabe por se esquecer da minha mensagem.

\section{Orestes}

Que garantia pretendes? De que precisas?

IFIGÉNIA

(735) Que ele me jure que levará estes escritos a Argos e que os dará aos entes queridos a quem os destino.

\section{Orestes}

E, em troca, tu jurarás também?

IFIGÉNIA

Sobre o que devo ou não fazer? Diz-me!

\section{Orestes}

Que o deixas sair vivo desta terra bárbara.

IFIGÉNIA

(740) É justo o que me pedes. De qualquer modo, como entregaria ele a mensagem se assim não fosse?

\section{Orestes}

E o rei? Estará de acordo?

IFIGÉNIA

Claro! Eu própria o convencerei, tal como serei eu a pôr o nosso amigo ${ }^{52}$ dentro do navio.

\section{Orestes}

Jura! E tu inicia também um juramento sagrado! ${ }^{53}$

IFIGÉNIA

Tens de dizer: «Entregarei esta mensagem aos teus entes-queridos.»

\section{Pílades}

(745) Darei estes escritos aos teus entes-queridos.

52 Pílades.

${ }^{53}$ Orestes dirige-se aos dois interlocutores, primeiro a Ifigénia e depois a Pílades. 
IFIGÉNIA

E eu ponho-te a salvo, para além das Rochas Negras.

Pílades

Por qual dos deuses fazes o teu juramento?

IFIGÉNIA

Por Ártemis, em cujo templo desempenho este ofício!

Pílades

E eu pelo senhor do céu, o sagrado Zeus!

IFIGÉNIA

(750) E se quebrares o juramento e me enganares?

Pílades

Que jamais regresse! E se tu não me salvares?

IFIGÉNIA

Que, enquanto viver, jamais volte a pisar o chão de Argos.

\section{PÍlades}

Ouve agora uma outra questão, que deixámos de lado.

IFIGÉNIA

Vamos, partilha-a connosco, se é para o nosso bem.

PÍlAdes

(755) Concede-me uma excepção. Se o navio sofrer algum dano ou se a tabuinha vier a desaparecer entre as ondas juntamente com outras coisas e apenas o meu corpo se salvar, que eu não fique preso a este juramento.

IFIGÉNIA

Então, sabes o que farei, uma vez que muitas precauções garantem †muitas† hipóteses? ${ }^{24}$ (760) Vou dizer-te por

${ }^{54} \mathrm{O}$ texto original é bastante sintético neste passo. Literalmente: "Muitas alcançam muitos.» 
palavras tudo o que está escrito nas várias tabuinhas, para que o possas repetir aos meus entes-queridos. Assim terei a certeza. Se salvares o escrito, ele relatará em silêncio o que contém registado; se essas letras desaparecerem no mar (765) e te salvares, salvarás também as minhas palavras.

\section{Pílades}

Boa sugestão, para ti e para mim. Diz-me então a quem, em Argos, devo levar esta mensagem e o que devo dizer daquilo que ouvir

\section{IFIGÉNIA}

Diz a Orestes, o filho de Agamémnon: (770) «Aquela que foi sacrificada em Áulis envia-te esta mensagem: "Ifigénia vive, ainda que esteja morta para os daqui!”»

\section{Orestes}

Onde está ela? Voltou, depois de ter morrido?

IFIGÉNIA

É esta mesmo para quem estás a olhar! Não me interrompas com os teus comentários! «Leva-me para Argos, ó sangue do meu sangue, antes que eu morra! Retira-me desta terra bárbara e livra-me dos sacrifícios da deusa, (775) em que tenho a função de matar estrangeiros!»

\section{Orestes}

Pílades, o que posso dizer? Onde é que nós estamos?

\section{IFIGÉNIA}

"Caso contrário, tornar-me-ei maldita para a tua casa, Orestes!» Por ouvires este nome duas vezes, aprendê-lo-ás melhor.

\section{Orestes}

(780) Ó deuses! 


\section{IFIGÉNIA}

Porque invocas os deuses num assunto que só a mim diz respeito?

\section{Orestes}

Por nada! Acaba! Estava a pensar noutra coisa!

\section{IFIGÉNIA}

Quando te interrogar, rapidamente ele se dará conta do inacreditável. Diz-lhe então que a deusa Ártemis me salvou, colocando uma corça no meu lugar. O meu pai ofereceu-a em sacrifício, (785) convencido de que era sobre mim que lançava o gume da espada. Depois, a deusa instalou-me nesta terra. Aqui tens a mensagem, eis o que está escrito nas tabuinhas.

\section{Pílades}

Fáceis são os juramentos com que me prendes! Ó mais bela das promessas! Não esperarei muito tempo para cumprir o que prometi. (790) Olha, Orestes, trago comigo uma tabuinha da parte desta tua irmá. Aqui a tens.

\section{Orestes}

Está entregue. Começarei, todavia, não por ouvir meras palavras, mas por pôr de lado as tabuinhas escritas e entregar-me ao prazer, ó minha mais que amada irmã. (795) Perplexo, abraço-te com braços incrédulos e alegro-me ao saber o que me deixa maravilhado!

\section{IFIGÉNIA}

Não tens o direito de tocar na serva da deusa, estrangeiro, nem de pôr as mãos no peplo intocável ${ }^{55}$.

\section{Orestes}

(800) Ó minha irmã, nascida do mesmo pai,

$55 \mathrm{O}$ peplo é uma peça de vestuário grego, uma túnica essencialmente feminina. 
Agamémnon, não me vires as costas! Aqui tens o teu irmão, quando pensavas que nunca mais o verias...

IFIGÉNIA

Tu? Meu irmão? Não acabarás com esta conversa? É em Argos que ele domina, ou em Náuplia...

Orestes

(805) Não é aí que o teu irmão está, infeliz!

IFIGÉNIA

Mas, tu foste gerado pela lacónia tindárida? ${ }^{256}$

Orestes

Nasci do neto de Pélops.

IFIGÉNIA

Que dizes? Tens provas para me apresentar?

Orestes

Tenho! Interroga-me acerca da casa paterna a que pertenço.

IFIGÉNIA

(810) Não deverias ser tu a falar e eu a ouvir?

\section{Orestes}

Primeiro que tudo, vou contar-te o que ouvi a Electra. Sabes que houve uma disputa entre Atreu e Tiestes?

IFIGÉNIA

Ouvi dizer. Uma discórdia por causa de um cordeiro de ouro ${ }^{57}$.

\section{Orestes}

Então sabes também que a teceste numa tela de fina textura.

\footnotetext{
${ }^{56}$ Clitemnestra.

${ }^{57}$ Ver notas 3 e 23.
} 
IFIGÉNIA

(815) Ó meu querido, tocas as minhas memórias...

\section{Orestes}

E nela incluíste a imagem da mudança do percurso do Sol ${ }^{58}$.

\section{IFIGÉNIA}

Sim, também bordei essa imagem no fino tecido.

\section{Orestes}

E recebeste da tua mãe o banho nupcial, em Áulis?

\section{IFIGÉNIA}

Bem sei, pois o casamento não foi tão feliz que o esquecesse.

\section{Orestes}

(820) E então? Deste madeixas do teu cabelo para que as entregassem à tua mãe?

\section{IFIGÉNIA}

Sim, dei, para que servisse de memória no meu túmulo, na vez do meu corpo.

\section{Orestes}

Quanto ao que eu próprio vi, eis o que te apresento como prova: a velha lança que Pélops brandiu, quando ao matar Enómao conseguiu para si Hipodamia, a virgem de Pisa, (825) estava na casa de meu pai, escondida junto das virgens do teu séquito! ${ }^{19}$

\section{(Ifigénia e Orestes abraçam-se.)}

\section{IFIGÉNIA}

Ó meu irmão mais querido, pois és o que de mais

${ }^{59}$ Ver nota 3. 
querido possuo, Orestes, †ó meu querido menino, da minha terra pátria†, (830) de Argos, ó meu querido!

\section{Orestes}

E eu tenho-te a ti, que já pensava morta!

\section{IFIGÉNIA}

As lágrimas, o lamento humedece os teus olhos e os meus ao mesmo tempo que a alegria! †Este† (835) é o bebé que deixei ainda recém-nascido nos braços da sua ama, mal acabava de vir ao mundo em casa. Ó alma minha, que és mais bem-aventurada do que as palavras conseguem exprimir! $\mathrm{O}$ que posso dizer? Tudo isto vai além (840) da maravilha que se possa verbalizar.

Orestes

Que doravante sejamos felizes, juntos.

\section{IFIGÉNIA}

Um inusitado prazer toma conta de mim, amigas! Temo que ele voe e escape das minhas mãos para o éter ${ }^{60}$. Ai lar ciclópico! ${ }^{61}$ (845) Ai pátria, minha querida Micenas! Obrigada por lhe teres dado vida! Obrigada por teres alimentado este meu irmão, por o teres criado como uma luz para a minha casa!

\section{Orestes}

Fomos afortunados na linhagem, minha irmá, (850) mas as circunstâncias tornaram a nossa vida desafortunada.

\section{IFIGÉNIA}

Bem sei, infeliz que sou! Sei como o meu pobre pai me feriu o pescoço com uma espada.

${ }^{60} \mathrm{O}$ aither, regiáo superior do ar, é também o termo usado pelos Gregos para designar o "céu», enquanto morada dos deuses.

${ }^{61}$ Micenas fora construída pelos Ciclopes. 


\section{Orestes}

(855) Ai de mim! Pois apesar de lá não ter estado, parece-me que te estou a ver.

IFIGÉNIA

Quando à traição me levavam para o leito onde Aquiles dormia, não havia cântico de Himeneu, meu irmão. (860) Junto ao altar, só havia lágrimas e lamentos. Ai, ai, que lustraçóes aquelas! < Ai de mim!>

\section{Orestes}

Também eu lamentei o acto cruel praticado pelo meu pai.

\section{IFIGÉNIA}

Sem pai, ficar sem pai foi o destino que me tocou. (865) Mas umas coisas nascem das outras, (867) por determinaçáo de alguma divindade.

\section{Orestes}

(866) E se tivesses matado o teu irmão, desgraçada?

\section{IFIGÉNIA}

(868) Que infeliz teria sido nessa horrível resolução! Imaginei algo de terrível, algo de terrível imaginei! Ai de mim, meu irmão! (870) Escapaste por pouco a uma morte ímpia, a ser abatido pelas minhas próprias mãos. (875) Como terminará toda esta thistóriał? Que sorte me acompanhará? Qual, <sim qual>, será o caminho que encontrarei para te levar desta cidade, e te livrar da morte, e assim enviar-te para a pátria de Argos, (880) antes que a espada se enterre no teu sangue? É isso, é isso, ó pobre alma, que tens de decidir. Deverá ser por terra, a pé, e não de navio? Vais cruzar-te com a morte, num errar por entre tribos bárbaras e (885) por caminhos que na verdade náo são caminhos. Por entre as escuras rochas do estreito, (890) 
longa é a estrada para a passagem de uma nau. Desgraçada, ó desgraçada! †Que deus, que mortal ou que (895) acontecimento inesperado nos proporcionará uma solução para este beco sem saída $\dagger$, para livrar do mal os únicos dois Atridas que ainda existem? ${ }^{62}$

\section{Coro}

(900) Não há palavras que descrevam esta maravilha que eu própria presenciei, não foi a mensageiros que a ouvi.

\section{PílLAdes}

É normal, Orestes, que quando pessoas que se querem se encontram, se dêem as mãos e se abracem. Mas há que acabar com os lamentos e concentrarmo-nos, para nos salvarmos e sairmos desta terra bárbara, por mais glorioso que este espectáculo seja. [É próprio de homens sábios não deixar escapar a sorte, mas antes aproveitar a oportunidade e só depois gozar outros prazeres].

\section{Orestes}

Tens razão. Suponho que temos a sorte do nosso lado. (910) Se se for resoluto, será normal que a vontade divina também se fortifique.

\section{IFIGÉNIA}

Não consegues impedir-me ou demover-me de, em primeiro lugar, te perguntar pelo destino que coube a Electra, pois †todos vós me são † queridos.

\section{Orestes}

(915) Vive com este amigo ${ }^{63}$ e tem uma vida abençoada pelos deuses.

\section{IFIGÉNIA}

E esse vem de que país e de quem é filho?

${ }^{62}$ Ifigénia desconhece ainda que a irmã, Electra, também está viva.

${ }^{63}$ Orestes refere-se a Pílades. 
Orestes

O pai chama-se Estrófio, o focense.

IFIGÉNIA

Será o filho da filha de Atreu ${ }^{64}$ ? Da minha família?

Orestes

Sim! É teu primo em primeiro grau, e o único que reconheço como meu amigo.

IFIGÉNIA

(920) Ainda ele não tinha nascido, quando o meu pai me sacrificou.

\section{Orestes}

Não, não tinha, pois Estrófio esteve algum tempo sem ter filhos.

IFIGÉNIA

Saúdo-te, então, marido da minha irmã.

\section{Orestes}

Ele é o meu salvador, não apenas um parente.

IFIGÉNIA

Como ousaste cometer actos tão terríveis contra a nossa mãe?

\section{Orestes}

(925) Não falemos dessas coisas. Foi para vingar o meu pai.

\section{IFIGÉNIA}

Porque matou ela o marido?

\section{Orestes}

Esquece a nossa mãe. Não vais gostar de ouvir...

\footnotetext{
${ }^{64}$ Ifigénia refere-se a Anaxíbia.
} 
IFIGÉNIA

Então calo-me. E Argos, ainda te obedece?

Orestes

É Menelau quem governa. Eu ando fugido da pátria.

IFIGÉNIA

(930) Não terá o nosso tio invadido uma casa desolada?

\section{Orestes}

Não! Na verdade, foi o medo das Erínias que me expulsou da minha terra.

IFIGÉNIA

(934) Estou a ver. As deusas levaram<-te> a isso, por causa da nossa mãe.

Orestes

(935) Foi como se me pusessem um freio de sangue.

IFIGÉNIA

(932) Foi então essa a loucura que se anunciou aqui na costa.

\section{Orestes}

Esta não é a primeira vez que me vêem vencido pela desgraça.

IFIGÉNIA

(936) E porque te encaminhaste para esta terra?

\section{Orestes}

Vim cumprir uma ordem de Febo.

IFIGÉNIA

$\mathrm{O}$ que tens de fazer? Podes dizer-mo ou vais manter-te em silêncio?

\section{Orestes}

Não, eu digo-te. Foi assim que começaram os meus 
muitos trabalhos. As Erínias perseguem-me como a um fugitivo desde que todos estes males, relacionados com a minha mãe - de que prefiro não falar -, me atingiram. Lóxias $^{65}$ conduziu então †os meus passos até Atenasł, para oferecer justiça a essas deusas sem nome ${ }^{66}$. (945) Pois ali há um tribunal sagrado, que Zeus instituiu para Ares, por causa da poluição que lhe sujara as mãos ${ }^{67}$. Ao chegar lá, a princípio, nenhum dos anfitrióes <me> mostrou boa vontade, visto eu ser odiado pelos deuses. Mas depois, os que tiveram vergonha ofereceram-me, por hospitalidade, uma mesa, mas à parte, (950) ainda que sob o mesmo tecto. Não falavam comigo, mantinham-me em silêncio, para que eu aproveitasse a comida e a bebida apartado deles. Tinham prazer em encherme uma taça apropriada, com uma medida digna de Baco. (955) Eu não tinha o direito de censurar os meus anfitrióes, sofria em silêncio, fingindo não perceber o que se passava; mas lamentava-me profundamente por ser o assassino da minha mãe. Ouvi dizer que as minhas desventuras se tornaram um ritual iniciático para os Atenienses e que ainda permanece o costume de o povo de Palas ${ }^{68}$ honrar o côngio ${ }^{69}$.

${ }^{65}$ Epíteto aplicado a Apolo enquanto divindade oracular.

${ }^{66}$ As Erínias. A coibição de pronunciar o nome destas divindades relacionava-se com os perigos inerentes à nomeação de deusas táo tenebrosas e destrutivas.

${ }^{67} \mathrm{O}$ areópago teria sido usado pela primeira vez quando os deuses julgaram Ares, o deus da guerra, pelo assassínio de Halirrótio, filho de Posídon. Halirrótio violara Alcipe, filha de Ares, e este vingou-se, matando o prevaricador. Daí o julgamento a que foi sujeito. Cf. Pausânias 1.21.7.

${ }_{68}^{68}$ Atena.

${ }^{69}$ Orestes alude à celebração iniciática, ligada às vindimas e ao vinho, que tinha lugar no segundo dia das Antestérias, festas associadas ao florescimento da natureza. Nesse dia, conhecido como «dia dos jarros» ou "dia dos côngios", a prova do vinho novo transformava-se numa competição em que cada celebrante bebia, numa mesa separada, a sua medida de vinho numa vasilha especial, conhecida como khoos, e que tinha capacidade para cerca de 3,24 litros. 
(960) Quando cheguei à colina de Ares, fui a julgamento. Tomei um dos assentos, enquanto o outro foi ocupado pela mais velha das Erínias ${ }^{70}$. Depois de falar e de ter ouvido falar do sangue da minha mãe, (965) Febo salvou-me, como minha testemunha. Palas beneficiou-me, ao pôr na urna, com o braço estendido, um número igual de pedrinhas ${ }^{71}$. Saí dali, depois de vencer aquele ordálio de sangue. Todos os que aceitaram a sentença se mantiveram sentados e marcaram-se os limites de um espaço sagrado com as pedras da votação ${ }^{72}$. (970) Mas, as Erínias que contestaram a lei iniciaram uma perseguição sem fim, sem me deixar parar, até que cheguei ao chão sagrado de $\mathrm{Febo}^{73}$. Deitei-me à entrada do santuário, sem comer. Lá, jurei que poria fim à vida e morreria, caso Febo não me salvasse, já que ele me destruíra. (975) Dali, fazendo soar a voz da sua trípode dourada, Febo enviou-me para cá, em busca da estátua que caiu do céu, para a erguer no solo de Atenas. Ajuda-me, portanto, no salvamento que ele determinou para mim. (980) Pois se nos apoderarmos da imagem de madeira, acabarei com a loucura que me aflige, embarcarei no navio de muitos remos e levar-te-ei de novo para Micenas. Portanto, minha querida, minha querida irmá, salva a casa paterna e salva-me a mim. (985) Tudo estará perdido, para mim e para os Pelópidas, se não conseguirmos a estátua de madeira da deusa, que caiu do céu.

${ }^{70} \mathrm{O}$ acusado sentava-se numa pedra que recebia o nome de «Pedra da hybris» ou "da ofensa»; o acusador sentava-se na "Pedra da anaideia» ou "da implacabilidade». Sobre o processo aqui evocado, ver Ésquilo, Euménides 566-1046.

${ }^{71}$ A personagem refere-se às psephoi, pequenas pedras polidas que eram usadas para contar o número de votos que se colocavam numa hydria. Ver Ésquilo, Euménides 674-806.

${ }^{72} \mathrm{O}$ texto refere-se ao final das Euménides de Ésquilo, em que Atena convence as Erínias a aceitarem um lugar para habitarem, junto do templo de Erecteu, em Atenas.

${ }^{73}$ Delfos. 


\section{Coro}

A terrível ira das divindades fervilha e arrasta para o sofrimento a semente de Tântalo ${ }^{74}$.

\section{IFIGÉNIA}

Eu já tinha vontade de regressar (990) a Argos e de te ver, meu irmão, antes de cá chegares. Quero o mesmo que tu: libertar-te de penas e reerguer a casa paterna, desolada, sem qualquer rancor contra quem me matou. $\dagger E$ E que quero! $\dagger$ Libertaria assim (995) a minha mão do teu sacrifício e salvaria também a nossa casa. Mas tenho medo de não ser capaz de iludir a deusa e o rei, quando ele encontrar vazio o pedestal de mármore da estátua. Como fazer para escapar à morte? Que justificação lhe darei? Mas se †tudo isto acontecer de uma vez só† (1000), se carregares a estátua e me levares sobre a bela proa do navio, o risco valerá a pena. Se assim não for, estarei perdida. Tu, porém, na posse de tudo aquilo de que necessitas, terás um bom regresso. Mas nem por isso eu recuo, mesmo que tenha de morrer para te salvar. Na verdade, se um homem morre, a casa sente a sua falta; (1005) a vida de uma mulher, porém, não tem valor.

\section{Orestes}

Não me tornarei o teu assassino, como o fui da minha mãe. Basta o sangue dela. Quero partilhar os meus sentimentos contigo. Vivo ou morto, quero ter o mesmo destino. (1010) Vou levar-te para casa, se eu próprio lá chegar. Ou ficarei aqui e aqui morrerei. Ouve o que penso: se esta solução for hostil a Ártemis, porque me teria Lóxias enviado o oráculo para levar a estátua da deusa para a cidade de Palas

$$
<>^{75}
$$

\footnotetext{
${ }^{74}$ Os descendentes de Tântalo são as casas de Atreu e Tiestes.

${ }^{75}$ Falta-nos o texto original.
} 
(1015) e que contemplasse o teu rosto? Assim, ponderando tudo, tenho esperança de que consigamos regressar.

IFIGÉNIA

Então, como havemos de fazer para não morrermos e conseguirmos o que queremos? É este o ponto fraco no plano de regresso a casa. É isto que há que ponderar.

Orestes

(1020) Seria possível matar o rei?

IFIGÉNIA

O que estás a dizer é terrível! Tornares-te o assassino do teu anfitrião.

Orestes

Mas se nos salvar... há que tentar.

IFIGÉNIA

Eu não seria capaz... mas admiro a tua audácia.

Orestes

E se me escondesses em segredo neste templo?

[IFIGÉNIA

(1025) Para aproveitarmos a escuridão e através dela nos salvarmos?

\section{Orestes}

Pois a noite está para os ladróes como a luz está para a verdade.]

\section{IFIGÉNIA}

Mas lá dentro estão os vigias do templo, a quem não conseguiremos escapar.

Orestes

Ai de mim! Estamos perdidos! Como nos salvaremos? 


\section{IFIGÉNIA}

Creio que tenho uma outra ideia.

\section{Orestes}

(1030) Que ideia? Conta-me o que te vai no pensamento para que fique a sabê-lo.

IFIGÉNIA

Terei de recorrer aos teus sofrimentos como estratagema.

\section{Orestes}

As mulheres são terríveis para inventar artimanhas.

IFIGÉNIA

Direi que vens de Argos e que mataste a tua mãe.

\section{Orestes}

Se for para o nosso bem, recorre então às minhas desgraças.

\section{IFIGÉNIA}

(1035) Direi que não é lícito sacrificar-te à deusa.

\section{Orestes}

Que razão terás para isso? Talvez já desconfie...

IFIGÉNIA

Direi que não estás puro, que sacrificarei apenas o que está santificado.

\section{Orestes}

E como será, desse modo, mais fácil conseguir a estátua da deusa?

\section{IFIGÉNIA}

Vou querer purificar-te com as águas do mar.

\section{Orestes}

(1040) Mas a imagem de madeira da deusa, pela qual navegámos, está no templo. 


\section{IFIGÉNIA}

E direi que também ela terá de ser purificada, pois tu tocaste-lhe.

\section{Orestes}

E onde? Estás a falar do promontório húmido, junto ao mar?

\section{IFIGÉNIA}

Onde, com amarras de linho, o teu navio está ancorado.

\section{Orestes}

E serás tu mesma ou outrem a levar a estátua de madeira nos braços?

IFIGÉNIA

(1045) Eu, pois só a mim é lícito tocá-la.

\section{Orestes}

E aqui Pílades, que lugar terá no nosso plano?

IFIGÉNIA

Direi que tem nas mãos a mesma mácula que tu.

\section{Orestes}

Farás tudo isso em segredo, em relação ao soberano, ou com o conhecimento dele?

\section{IFIGÉNIA}

Vou persuadi-lo com palavras, pois de modo algum conseguiria esconder-me. (1049) E tu trata do resto, (1051) para que tudo corra bem.

\section{Orestes}

(1050) Pois bem, os remos do navio estão preparados para navegar. (1052) Falta apenas uma coisa: que estas 
mulheres fiquem caladas ${ }^{76}$. Fala com elas e procura usar palavras persuasivas. A mulher tem o poder da compaixão. Quanto ao resto, (1055) estou certo de que tudo correrá bem.

\section{IFIGÉNIA}

Queridas companheiras, ponho o meu olhar em vós, pois em vós está o meu êxito ou o meu desaire, vendo-me neste caso privada da pátria, do meu muito amado irmão e da minha muito querida irmá. E que este seja o meu primeiro argumento: somos mulheres, (1060) género que gosta de se entreajudar e que se mantém firme quando se trata de assegurar interesses comuns. Ajudai à nossa fuga com o vosso silêncio. Uma língua leal é bela para quem a possui. (1065) Vede como uma só sorte é comum a três pessoas que se amam: ou o regresso à terra pátria ou a morte. Se me salvar, vou levar-vos a salvo para a Hélade, para que comunguemos da mesma sorte. Mas, pela vossa mão direita, vos suplico, a ti e a ti, pela tua face e pelos teus joelhos ${ }^{77}$, (1070) e pelos que mais amas na tua casa, [mãe, pai e filhos, caso os tenhas]. O que dizeis? Qual de vós diz que aceita ou que não aceita? Dizei alguma coisa, pois se não aceitardes as minhas palavras estarei arruinada e o meu irmão desgraçado.

\section{Coro}

(1075) Coragem, querida senhora! Trata apenas de te salvar! Quanto a mim, manterei o silêncio sobre tudo o que está planeado. (Que o saiba o grande Zeus!)

\section{IFIGÉNIA}

Fico grata pelas vossas palavras e desejo-vos felicidades! A tua tarefa e a tua é a de ir para dentro do templo. Já a seguir, (1080) estará aqui o governante desta terra, a perguntar se levei a cabo o sacrifício dos estrangeiros. Ó senhora, que na

\footnotetext{
${ }^{76}$ Orestes refere-se às servas do coro.

77 Alusáo ao acto de suplicante.
} 
encosta de Áulis me salvaste das terríveis mãos do meu pai assassino, salva-me também agora, a mim e a eles, (1085) ou a boca de Lóxias ${ }^{78}$ não será, por tua causa, fidedigna perante os mortais. Sê benevolente, sai desta terra bárbara e vai para Atenas, pois também não te convém morar aqui em vez de estares numa cidade abençoada.

\section{(Ifigénia, Orestes e Pilades entram no templo.)}

\section{Coro}

\section{Estrofe 1}

Alcíone, ave que sobre as cordilheiras rochosas (1090) do mar cantas um lamento de desgraça, um grito que, quem sabe, sabe que cantas pelo teu esposo, soando eternamente a água fervilhante ${ }^{79}$. (1095) Eu acompanho-te com cantos de lamento ${ }^{80}$, qual pássaro sem asas, suspirando pelas assembleias dos Helenos, suspirando por Ártemis Parteira ${ }^{81}$, a que habita na cordilheira de Cinto $^{82}$, bem como pela palmeira de luxuriante folhagem e pelo loureiro exuberante (1100); pelo sagrado ramo da oliveira glauca, caro às dores de parto de Leto, e pelo lago que faz a sua água rodar em círculos, (1105)

${ }^{78}$ Apolo.

${ }^{79}$ Mito da alcíone. Alcíone era uma filha de Éolo, senhor dos ventos, que se casara com Ceíce, filho do Astro da Manhã. O casal era tão feliz que se comparava a Zeus e Hera. Os deuses, porém, não gostaram da vaidade e transformaram-nos em dois pássaros: a ele num mergulháo; a ela em alcíone. Esta construía o seu ninho à beira mar, o que fazia com que as ondas o destruíssem sempre. Zeus compadeceu-se dela e ordenou aos ventos que se acalmassem durante os sete dias que precedem e os sete que se sucedem ao solstício de Inverno. É precisamente esse o período em que a alcíone choca os seus ovos. O pio lamentoso da ave traduzia o sofrimento que sentia pela perda do outrora seu marido. Sobre este mito, ver Higino, Fábulas 65; Ovídio, Metamorfoses 9, 410-750.

${ }^{80}$ Trenos.

$81 \mathrm{O}$ coro refere-se à epifania helénica de Ártemis, enquanto deusa protectora dos partos e das parturientes.

${ }^{82}$ Localizada em Delos. 
onde o cisne melodioso presta serviço às Musas.

\section{Antistrofe 1}

Oh! Abundantes foram as lágrimas que me correram pelas faces quando, depois das torres destruídas, me levaram em navios, entre remos (1110) e lanças de guerra. Como mercadoria valiosa em ouro, viajei para junto dos bárbaros, onde cuido da rapariga que serve a deusa matadora de veados ${ }^{83}$, (1115) a que é filha de Agamémnon, e dos altares em que não se sacrificam ovelhas. Invejosa sou de quem sempre foi desafortunado, pois esse, ao ser criado com o infortúnio, não sofre tanto nas necessidades por que passa. (1120) Desgraça é a mudança e penoso é, na vida dos mortais, surgirem afliçóes depois de se ter sido afortunado.

Estrofe 2

A ti senhora, um pentecôntoro ${ }^{84}$ argivo (1125) te levará a casa. Unida com cera, a flauta ${ }^{85}$ de Pã das montanhas tocará e encorajará os remos do navio. E Febo, o adivinho ${ }^{86}$, cantando ao som da sua lira de sete tons, (1130) há-de levar-te a bom porto para a terra brilhante dos Atenienses. $\dagger$ Deixando-me aqui, irás ao som dos remos ruidosos. (1135) Os cabos da †nau rápida†, como se tivesse pés, estenderão a vela sobre a proa ao sabor do vento e assim farás a viagem. $\dagger$

Antistrofe 2

Pudesse eu andar sobre luminosas estradas por onde passam cavalos, por onde caminha o fogo brilhante como o Sol. (1140) Deixaria de agitar as asas nas minhas costas, ao chegar ao tálamo e ao regressar a casa. Fizesse eu

83 Ártemis.

${ }^{84}$ Navio grego de cinquenta remos.

${ }^{85} \mathrm{Na}$ verdade, Eurípides refere-se às "canas de Pá», utilizando depois o verbo syrizo, que define o nome grego do instrumento em causa, siringe, através da sua função.

${ }^{86}$ Apolo. 
parte de coros em que, †qual virgem em gloriosas bodas, (1145) rodopiasse junto da minha mãe e com bandos de companheiras competisse com as Cárites ${ }^{87}$, ao usar longos e ricos penteados, atando com multivariados atilhos (1150) madeixas de cabelo que fizessem sombra às minhas faces. $\dagger$

(Toas, o rei dos Tauros, entra em cena, acompanhado de alguns servos.)

\section{TOAS}

Onde está a mulher helena, a guardiã das portas deste templo? Já começou o ritual com os estrangeiros? (1155) [Já ardem os corpos no fogo dos recintos sagrados?]

\section{Coro}

Está aqui, soberano, aquela que te contará tudo, de forma clara!

\section{TOAS}

Pois bem! Porque tiraste do pedestal fixo a estátua da deusa e a tens nas tuas mãos, filha de Agamémnon?

(Ifigénia aparece à porta do templo. Traz consigo a estátua de Ártemis.)

\section{IFIGÉNIA}

Detém os teus passos aqui, na ombreira da porta, soberano!

TOAS

(1160) O que há de novo no templo, Ifigénia?

IFIGÉNIA

Cuspo, pois à pureza sagrada devo esta palavra. ${ }^{88}$

${ }^{87}$ As Graças, divindades da beleza, ligadas ao universo da vegetação.

${ }^{88}$ Ritual que tem como função repelir a poluição encorajada pelas palavras de Toas. 
TOAS

Que novidade estás a insinuar? Fala com clareza!

IFIGÉNIA

As vítimas sacrificiais que capturaste não estão puras, soberano.

TOAS

O que te dá essa certeza? Ou estás apenas a dar-me a tua opiniáo?

IFIGÉNIA

(1165) A imagem de madeira da deusa virou-se de costas, no pedestal.

\section{TOAS}

Por si mesma ou foi algum tremor de terra que a virou?

IFIGÉNIA

Por si mesma! E vimos também que fechou os olhos.

TOAS

E porquê? Por asco aos estrangeiros?

IFIGÉNIA

Foi por isso e não por outra coisa. Pois fizeram algo de terrível...

TOAS

(1170) Mataram algum dos bárbaros, no promontório? ${ }^{89}$

IFIGÉNIA

Já cá chegaram com um crime cometido em casa.7

ToAs

Qual? Sinto um grande desejo de sabê-lo...

${ }^{89}$ É curioso como Toas se refira aos do seu próprio povo como «bárbaros», o que corresponde a uma visão helenocêntrica de Eurípides. Ver Silva 2005, 187-237. 
IFIGÉNIA

Usaram a espada contra a própria mãe...

TOAS

Por Apolo! Nenhum de entre os bárbaros faria tal coisa...

\section{IFIGÉNIA}

(1175) Foram perseguidos e expulsos por toda a Hélade.

ToAs

E será por causa deles que estás a levar a estátua?

IFIGÉNIA

Levo-a para debaixo do sagrado éter, para a afastar do crime.

\section{TOAS}

E como conseguiste saber qual era a mácula dos estrangeiros?

\section{IFIGÉNIA}

Interroguei-os, quando virei de novo a imagem de madeira da deusa.

TOAS

(1180) Sábia te criou a Hélade! Com bom discernimento.

IFIGÉNIA

E no entanto puseram um doce engodo no meu coração.

\section{TOAS}

Transmitiram-te alguma mensagem enfeitiçada de Argos?

\section{IFIGÉNIA}

Disseram-me que o meu único irmão, Orestes, é feliz... 
Toas

Com o intuito de que o prazer proporcionado pelas notícias te leve a salvá-los?

IFIGÉNIA

(1185) ... e também que o meu pai está vivo e que passa bem.

TOAS

Mas tu puseste-te ao lado da deusa, naturalmente.

IFIGÉNIA

Odiando toda a Hélade, que me matou.

TOAS

Diz-me então o que fazer com os estrangeiros.

IFIGÉNIA

Há que respeitar a lei estabelecida.

TOAS

(1190) Não estão as tuas lustrações e espada a funcionar?

IFIGÉNIA

Primeiro quero purificá-los com abluçôes sagradas.

TOAS

Com água das nascentes ou do mar?

IFIGÉNIA

O mar lava todos os males da Humanidade.

TOAS

Pelo menos cairão mais puros perante a deusa.

IFIGÉNIA

(1195) Sim, e também para mim será melhor.

TOAS

Decerto que não excluis o curso de água em frente do próprio templo... 


\section{IFIGÉNIA}

É preciso um sítio sossegado, pois faremos também outros rituais.

\section{TOAS}

Então leva-os até onde for necessário. Não gosto de ver o que é proibido.

\section{IFIGÉNIA}

Vou purificar a imagem de madeira da deusa.

TOAS

(1200) Claro, se a mácula do matricida a atingiu...

IFIGÉNIA

Ou nunca a teria retirado do pedestal.

TOAS

A tua piedade e a tua precaução são justas.

IFIGÉNIA

Agora sabes o que há a fazer.

TOAS

É tua função dizê-lo.

IFIGÉNIA

Prendei os estrangeiros!

TOAS

Para onde fugiriam?

IFIGÉNIA

A Hélade não sabe o que é a lealdade.

TOAS

(1205) Prendei-os, servos!

(Alguns dos servos de Toas entram no templo.)

IFIGÉNIA

Trazei aqui os estrangeiros. 
TOAS

Façam o que ela diz!

IFIGÉNIA

Com a cabeça coberta de véus.

TOAS

Para os esconder da luz do Sol!

IFIGÉNIA

Ordena que os que te seguem me acompanhem.

ToAs

Estes vão ser a tua escolta.

IFIGÉNIA

E que alguém se dirija à cidade e anuncie...

TOAS

Anuncie o quê?

IFIGÉNIA

(1210) ... que todos permaneçam em casa!

TOAS

Para não darem de caras com os assassinos?

IFIGÉNIA

Sim, pois eles estão impuros.

(O rei dirige-se a um subordinado seu.)

TOAS

Vamos, tu mesmo faz essa proclamação!

IFIGÉNIA

Que ninguém se aproxime e os veja!

TOAS

Cuidas bem da cidade!

IFIGÉNIA

E dos amigos, acima de tudo! 
ToAs

Dizes isso por minha causa.

$<$ IFIGÉNIA

TOAS

Naturalmente, toda a cidade te admira.

IFIGÉNIA

Tu, fica aqui, junto ao templo da deusa!

TOAS

(1215) E o que faço?

IFIGÉNIA

Usa a tocha para purificar esta morada.

ToAs

Para que esteja limpa quando voltares.

IFIGÉNIA

E quando os estrangeiros estiverem a sair...

ToAs

O que devo fazer?

IFIGÉNIA

Cobre o rosto com um véu.

TOAS

Para não †ser contaminado $†$.

IFIGÉNIA

Se te parecer que demoro muito tempo...

ToAs

E que limite porei nisso?

IFIGÉNIA

(1220) ... não te admires. 


\section{ToAs}

Cuida bem do que é da deusa, demora o tempo que for necessário.

IFIGÉNIA

Que esta purificação se faça como desejo.

\section{TOAS}

Junto-me a ti nessa súplica.

(Orestes e Pílades saem do templo com as mãos atadas e as cabeças cobertas. Sáo escoltados pelos homens de Toas. O rei cobre também a sua cabeça.)

\section{IFIGÉNIA}

Já vejo os estrangeiros a sair do templo, os adornos da deusa e os cordeiros recém-nascidos, que expurgarão com o seu sangue o sangue impuro; já vejo o brilho das tochas e tudo o mais que especifiquei para (1225) a purificação dos estrangeiros e da deusa. Aviso os cidadáos que se mantenham afastados de toda esta poluição: quem for guardião do templo e tiver de manter as máos puras para os deuses, quem se vai unir em casamento, qualquer mulher no período de gravidez, que fuja, que saia deste lugar, não vá cair sobre esse alguém esta mácula. (1230) Ó soberana virgem, filha de Zeus e de Leto, se eu purificar estes homens do crime e oferecer um sacrifício onde ele é necessário, ficarás a habitar numa casa pura e nós seremos felizes. Quanto ao resto, nada digo. No entanto, dou um sinal aos deuses, que tudo sabem, e a ti, ó deusa!

(Ifigénia sai à frente da procissão. Toas entra no templo. O coro canta.)

\section{Coro}

Estrofe

O rebento de Leto, (1235) o dos cabelos doirados, o 
sábio tocador de cítara que se alegra com a habilidade do tiro ao arco, aquele a quem ela um dia $<$ deu à luz> no fértil vale de Delos, é um bom filho. Abandonando o ilustre lugar onde ocorreu o parto, a mãe levou-o (1240) das cordilheiras marinhas para o cimo do Parnaso ${ }^{90}$, onde as águas torrenciais sáo como bacantes celebrando os mistérios de Dioniso (1245) e a serpente de dorso matizado, da cor do vinho ${ }^{91}$, que se cobria no bosque de belas folhas debaixo do sombrio loureiro, †guardava o oráculo subterrâneo $\dagger$ qual gigantesco monstro da terra. (1250) Ainda criança, ainda nos braços da tua querida mãe, avançaste para a matar, ó Febo, e ocupaste o oráculo sagrado. Sentaste-te na trípode dourada, no trono da verdade, a transmitir oráculos por decreto divino para os mortais (1255) do interior do santuário vizinho das correntes castálias ${ }^{92}$, tendo morada no centro da terra.

\section{Antistrofe}

Depois de ter mandado embora Témis ${ }^{93}$, (1260) a filha de Geia ${ }^{94},<>$ do seu muito sagrado oráculo, Ctónia ${ }^{95}$ gerou fantasmas nocturnos, $s<$ onhos $>$ que mostravam a muitos dos mortais o passado, (1265) o presente e o futuro" quando dormiam nos seus leitos térreos. Para vingar a filha, Geia tirou a Febo a honra de adivinho. (1270) Com pés ágeis, logo o deus soberano se dirigiu ao Olimpo e abraçou o trono de Zeus com as mãos de criança, para que ele livrasse a casa

${ }^{90} \mathrm{Da}$ rochosa ilha de Delos, onde se localiza o Monte Cinto, até ao Monte Parnaso.

${ }^{91}$ Alusão ao mito da píton, morta por Apolo em Delfos.

${ }^{92}$ A fonte Castália localizava-se perto do santuário de Delfos e as suas águas eram usadas como meios de purificação.

${ }^{93}$ Titânide que tutelava a lei.

${ }^{94} \mathrm{~A}$ Terra, elemento primordial de que descendem as raças divinas.

${ }^{95}$ Outro nome da Terra.

${ }^{96}$ Literalmente: «as coisas primeiras, as coisas que prevalecem e as coisas que estáo para acontecer». 
pítia da cólera da deusa ctónica. Zeus riu-se, pois o jovem tinha vindo com toda a rapidez (1275) porque queria manter os seus cultos ricos em ouro. Agitou então a cabeleira para fazer cessar os gritos da noite, tirou aos mortais a evidência das visóes nocturnas (1280), dando de novo a Lóxias tais honras e aos homens a confiança nos cantos decretados pelo senhorm do trono que é visitado pelos peregrinos.

(Entra um mensageiro, que fora um dos servos de Toas a acompanhar o grupo chefiado por Ifigénia.)

\section{Mensageiro}

Guardiães do templo e intendentes dos altares, aonde foi Toas, o soberano desta terra? Abri as portas bem pregadas e chamai lá de dentro o nosso governante.

\section{Coro}

O que é? Se é que posso falar sem ter sido exortada a isso...

\section{Mensageiro}

Os dois jovens escaparam-se (1290), fugiram desta terra graças a um plano da filha de Agamémnon, levando a imagem sagrada de madeira, embarcados numa nau helénica.

\section{Coro}

O que disseste é inacreditável! Aquele que procuras, o senhor da terra, saiu do templo à pressa.

Mensageiro

(1295) Aonde foi? Pois é necessário que o próprio fique ciente do sucedido.

Coro

Não sabemos. Anda, segue-o até aos lugares onde o hás-de encontrar. Há que transmitir-lhe essa notícia. 


\section{Mensageiro}

Vede como é falho o género feminino. Vós também, sois cúmplices do que se passou.

\section{Coro}

(1300) Enlouqueceste! O que temos nós que ver com a fuga dos estrangeiros? Apressas-te ou não a ir até à porta do palácio?

\section{Mensageiro}

Não, enquanto algum intérprete ${ }^{97}$ não disser uma palavra sobre se o senhor da terra está ou não lá dentro. Eh!, vocês aí! Retirem as barras, as de dentro, quero dizer, (1305) e dêem a conhecer ao senhor porque estou aqui à entrada, portador de uma série de más notícias.

\section{(Toas sai do templo.)}

\section{TOAS}

Que alvoroço é este junto ao templo da deusa, quem bate à porta e faz barulho lá dentro?

\section{Mensageiro}

$\dagger$ Era mentira o que estas mulheres diziam, que $\dagger$ estavas fora, para me afastarem do templo. (1310) Afinal estás aqui.

TOAS

O que esperam ganhar com isso? Que ideia é a delas?

Mensageiro

Mais tarde te direi o que se passa com elas. Mas antes ouve o que está a acontecer. A jovem que aqui estava nos altares, Ifigénia, (1315) foi-se desta terra com os estrangeiros e levou a estátua sagrada da deusa. As purificaçōes eram um dolo.

\footnotetext{
${ }^{97} \mathrm{O}$ mensageiro fala como se procurasse a revelação de um oráculo.
} 
ToAs

O que dizes? Que triste ideia a possuiu?

Mensageiro

A de salvar Orestes! Vais ficar perplexo com isto.

ToAs

O quê, como? Aquele que é filho da filha de Tíndaro?

Mensageiro

(1320) Aquele que a deusa dedicou a estes altares.

TOAS

Extraordinário! Que palavra melhor encontrarias para esta situação?

\section{Mensageiro}

Não te distraias e ouve-me. Depois de veres e ouvires atentamente, pensa na perseguiçáo com que daremos caça a esses estrangeiros.

\section{TOAS}

(1325) Tens razão, portanto fala. Não é curta a rota que perseguem na fuga, pelo que não escaparão à minha lança.

\section{Mensageiro}

Depois de nós, a quem tu enviaste com as correntes para os estrangeiros, termos chegado à orla marítima, onde a nau de Orestes estava ancorada em segredo, a filha de Agamémnon (1330) fez sinal com a cabeça para que nos afastássemos, enquanto acendia a chama proibida e procedia à purificação que a lá levara. Ela própria tomou nas mãos os grilhôes dos estrangeiros e seguiu atrás deles. (1335) Isto era para desconfiar, mas ainda assim nós, os teus servos, achámos que estava tudo bem, senhor. Ela deixou passar um intervalo, para que pensássemos que fazia algo mais ali, e fez 
ouvir o grito ritual, entoou cânticos bárbaros, tal qual um mago, como que para lavar o crime. Depois de muito tempo sentados, (1340) lembrámo-nos de que os estrangeiros se tivessem soltado e a tivessem matado, para se porem em fuga. Mas como temíamos ver o que não devíamos, permanecemos imóveis, em silêncio. Por fim, acordámos todos em ir ao local, apesar de isso não nos ser permitido. (1345) Ali, vimos então a quilha da nau helénica guarnecida †com uma fileira de remos, como se fossem penas em asas, os cinquenta marinheiros que seguravam os remos pelas pásł, e os jovens sem as cadeias, livres, de pé sobre a popa. (1350) Alguns mantinham-se na proa junto ao mastro, outros amarravam a âncora ao turco, outros preparavam apressadamente a escada, lançando-a da proa sobre o mar, para a tornar acessível à estrangeira. Ao percebermos o enganoso esquema, deixámos de pensar em nós; (1355) lançámo-nos à estrangeira e aos cabos e tratámos de tirar o leme do navio de proa sólida, através das cavidades. Multiplicaram-se as perguntas: "Por que razão roubais e levais desta terra a imagem esculpida e a mulher encarregada dos sacrifícios? (1360) Quem és <tu> e de que terra és para a levares?» Ele respondeu: «Ficai a saber que sou Orestes, o irmão dessa mulher e filho de Agamémnon. Ao tomá-la, apenas tomo a minha irmã, que andava perdida de casa.» Nós não desistíamos de segurar a estrangeira, (1365) na tentativa de a trazermos à tua presença, apesar dos golpes terríveis que levámos na face. Nem eles nem nós tínhamos qualquer ferro nas mãos. Houve um combate, em que os dois jovens usaram os punhos e as pernas, para nos atingirem (1370) costelas e fígado. Perante o ataque, sentimos que os nossos membros se esgotavam. Vítimas de terríveis marcas, fugimos para uma encosta escarpada, com feridas sangrentas na cabeça e nos olhos. (1375) À cautela, instalámo-nos numa colina e 
combatemos lá de cima, lançando pedras. Mas os arqueiros, sobre a proa, atacaram-nos com flechas, e mantinham-nos à distância. Nisto (pois uma vaga terrível trouxe a nau (1380) para terra e porque < a virgem $>$ tinha medo de molhar os pés), Orestes tomou-a sobre o ombro esquerdo, avançou para o mar e saltou para a escada, pondo a irmã dentro da nau que estava bem à vista (1385), bem como a estátua da filha de Zeus, a que caiu do céu. Do meio da nau soou um grito: "marinheiros da terra da Hélade, tomai os remos e cobri-os do branco da espuma! Já temos aquilo que nos fez navegar pela passagem inóspita das Simplégades.» (1390) Com um alarido animoso, os marinheiros feriram as águas. Estando no porto, a nau arrancou para a saída; mas ao passar a barra, veio um vento súbito, que a impulsionou pela popa e a fez colidir com uma vaga furiosa. (1395) Eles persistiam, pontapeando as vagas. Mas as ondas em refluxo conduziram a nau de novo para terra. A filha de Agamémnon pôs-se de pé e orou: «Filha de Leto, salva-me, salva a tua sacerdotisa, levame desta terra bárbara para a Hélade e perdoa o meu roubo! (1400) Também tu, deusa, amas o teu irmão! Compreende que também eu amo os do meu sangue!» Os marinheiros gritaram em uníssono com o péan que continha a oração da jovem. Sob a voz do comando, ajustaram os remos aos ombros nus < de peplos>. (1405) A quilha do navio avançava cada vez mais contra as pedras. Então um lançou-se ao mar de pés e outro desatou os cabos enlaçados. Eu fui directamente enviado dali à tua presença, senhor, (1410) para te contar o que lá se estava a passar. Por isso, avança, vai munido de grilhóes e cordas. Se as vagas não acalmarem não haverá esperança de salvação para os estrangeiros. O senhor do mar, favorável a Ílio, o sagrado Posídon, contrário aos Pelópidas, (1415) há-de entregar-te e aos teus cidadãos aquele que, ao 
que parece, é o filho de Agamémnon, e colocar-te nas mãos a sua irmã, que, já esquecida do crime de Áulis, tu apanhaste a trair a deusa.

\section{Coro}

(1420) Pobre Ifigénia, morrerás de novo com o teu irmão, se cais outra vez nas mãos do tirano.

\section{Toas}

Que venham todos os cidadãos desta terra bárbara! Ponde as rédeas nos potros e correi ao longo da costa para saquear os destroços da nau helénica. (1425) Despachai-vos e, com a ajuda da deusa, haveis de capturar estes homens ímpios. Que outros metam rapidamente os barcos ao mar, para que os apanhemos no mar ou em terra, em cavalgada, para os arremessarmos contra (1430) as fragas rochosas ou lhes espetarmos o corpo num pau pontiagudo. De vós, mulheres, que sois cúmplices destes planos, hei-de vingarme no regresso, quando tiver oportunidade. Agora, face à urgência que se impóe, não ficarei quieto.

\section{(A deusa Atena aparece sobre o telhado do templo.)}

\section{Atena}

(1435) Aonde vais? Até onde levas esta perseguição, ó soberano Toas? Ouve as palavras de Atena! Pára de perseguir e de lançar a corrente do exército para a guerra. Se Orestes veio aqui foi por decreto de Lóxias, em fuga da cólera das Erínias, (1440) para conduzir a irmã para Argos e levar a estátua sagrada para a minha terra, e pôr fim aos sofrimentos presentes. É esta a mensagem que te dirijo. Quanto a Orestes, o homem que intentas matar apanhando-o na agitação das ondas, já Posídon, a meu pedido, (1445) acalmou o mar, para que ele possa remar de volta a casa. E tu, Orestes, sabendo o que determino (pois ouves a minha voz apesar de não estares 
presente), pega na estátua e na tua irmá e parte. Assim que chegares a Atenas, a fundada pelos deuses, (1450) há um território perto da fronteira da Ática, vizinho da cordilheira sagrada de Carístia, chamado Halas pelo meu povo ${ }^{98}$. Depois de construíres aí um templo, instalarás a imagem de madeira da deusa com o nome da terra táurica, em memória dos trabalhos (1455) que sofreste por toda a Hélade, sob o efeito do furor das Erínias. Doravante, os mortais entoarão hinos a Ártemis, a deusa Taurópola ${ }^{99}$, e será esta a prática: sempre que o povo celebrar a festa pelo resgate da tua morte, que se toque com uma espada (1460) o pescoço de um homem e se deixe correr o sangue como santificação, pois por meio dele a deusa terá as suas honras. E tu, Ifigénia, serás a encarregada das chaves nas pradarias sagradas de Bráuron ${ }^{100}$, junto da deusa, onde terás ritos funerários quando morreres ${ }^{101}$. Em tua honra, será oferecido (1465) o peplo de fina textura, que as mulheres que perderam a vida ao dar à luz deixam em casa ${ }^{102}$. Ordeno ainda que deixes partir desta terra as mulheres da Hélade, como paga pelo seu correcto julgamento. Já antes te salvei, Orestes, (1470) na colina de Ares, ao empatar os votos. E esta será a lei: que se absolva quem receber um número igual de $\operatorname{votos}^{103}$. Leva desta terra a tua irmã, filho de Agamémnon. E tu, Toas, não te enfureças.

TOAS

(1475) Ó soberana Atena, não pensa bem aquele que,

${ }^{98}$ Localidade na costa leste da Ática, a $25 \mathrm{~km}$ de Atenas. Halas era uma lagoa de água salgada, hoje seca, junto à qual se localizava o santuário de Ártemis.

${ }^{99}$ Adorada na Táurica.

${ }^{100}$ Referência ao culto de Ártemis Braurónia.

${ }^{101}$ Sugere-se que havia um culto de Ifigénia em Bráuron.

${ }^{102}$ Muitas mulheres ofereciam as suas roupas a Ártemis. É provável que se oferecessem também as roupas de mulheres mortas durante o parto.

${ }^{103}$ Etiologia para a prática jurídica e penal. 
ao ouvir as palavras dos deuses, lhes desobedece. Não quero mal a Orestes, por ele levar a imagem da deusa, nem à sua irmã. [Pois que proveito há na competição com os deuses poderosos?] (1480) Que vão para a tua terra com a estátua da deusa e que em boa hora lá a instalem! Enviarei também estas mulheres para a Hélade, terra de prosperidade, tal como a tua ordem exige. Não ergo mais esta lança contra os estrangeiros (1485) e travo os remos das naus, como desejas, deusa.

\section{Atena}

Louvo a tua decisão. É a necessidade que te controla e aos deuses. Ide, ó ventos, levai por mar para Atenas o filho de Agamémnon. Eu irei convosco na viagem e salvarei a imagem sagrada da minha irmá.

\section{(Atena sai.)}

\section{Coro}

(1490) Ide, em boa hora, graças a um destino feliz e salvador. Pois assim faremos, ó Palas Atena, ó augusta entre os imortais e os mortais, tal como ordenas. (1495) Na verdade, bem agradável e inesperada é a voz que nos é dada a ouvir. [Ó grande e sagrada $\mathrm{Nice}^{104}$, toma conta da minha vida e não deixes de coroar-me.]

(As servas gregas saem, acompanhadas por Toas e os seus homens.)

${ }^{104}$ A deusa da vitória. 
(Página deixada propositadamente em branco) 


\section{INDEX RERVM}

agamos: 20.

aither: 69 ก. 60.

anagnorisis: 18.

anaideia: 75 n. 70.

aphilos: 21 .

apolis: 20.

ateknos: 20.

corpus: $17,19$.

deus ex machina: 15, 24.

eidolon: 9.

hybris: 75 n. 70.

hydria: 75 n. 71 .

khoos: 74 n. 69.

libretto: 24.

limes: 11.

locus horrendus: 16.

pathos: 13.

Pedra da anaideia: 75 n. 70.

Pedra da hybris: 75 n. 70.

peripeteia: 18.

philia: 21.

psephoi: 75 n. 71.

thoazo: 34 n. 8.

thoos: 34 n. 8.

tyche: 17. 
(Página deixada propositadamente em branco) 


\section{INDEX LOCORVM}

Apolodoro

Biblioteca

3.10.1: 33 n. 3.

Apolónio de Rodes

Argonáutica

2.316-340: 38 n. 11.

Aristófanes

As mulheres que celebram as Tesmofórias

$$
\text { 1059-1061: } 7 \text { n. } 2 .
$$

Aristóteles

Poética

1452b5-7: 13 n. 13, n. 14.

1454a7: 13 n. 13.

1454b31-35: 13 n. 13, n. 14.

1455a17-19: 13 n. 13, n. 14.

Cantos Ciprios

frg. 17 Davies: 10 n. 10 .

frg. 24 Bernabé: 10 n. 10 .

frg. 32 Davies: 9 n. 7.

frg. 41 Bernabé: 9 n. 7.

Diodoro Sículo

$$
\text { 20.14: } 58 \text { n. } 48 .
$$

Eliano

Da natureza dos animais

14.28: 43 n. 31.
Eliano

Varia Historia

3.8: 7 .

Ésquilo

Euménides

566-1046: 75 n. 70.

Ésquilo

Euménides

674-806: 75 n. 71.

Ésquilo

Suplicantes

41 ss.: 47 n. 36.

Eurípides

Orestes

988ss.: 33 n. 2.

Heródoto

3.59: 38 n. 13.

4.103: 10 n. 9.

Hesíodo

frg. 23(a) Merkelbach-West: 9 n. 8.

Teogonia

629-900: 41 n. 27.

Higino

Fábulas

65: 81 n. 79. 
84: 33 n. 2.

253: 33 n. 2.

Iliada

2.104-108: 33 n. 3.

9.145: 10 n. 10.

9.287: 10 n. 10.

\section{Odisseia}

12.59-79: 38 n. 11.

12.201-231: 38 n. 11.

Ovídio

Heróides

8.70: 33 n. 3.

Ovídio

\section{Metamorfoses}

1.583-746: 47 n. 36.

9.410-750: 81 n. 79.

Pausânias

$$
\text { 1.21.7: } 74 \text { n. } 67 .
$$

Píndaro

Ode olimpica

1.40-90: 33 n. 3.

Séneca

Tiestes

222-244: 40 n. 23.

Sófocles

Electra

157: 10 n. 10.

504ss.: 33 n. 3.

530-531: 10 n. 10. 


\section{INDEX NOMINVM}

Agamémnon: 9-10, 10 n. 10, 11, 19, 33-34, 35 n. 9,38 n. 15 , $39,41,54-55,60,65,67,82-$ 83, 92, 94-99.

Alceste: 19.

Alcibíades: 8.

Alcíone: 81; 81 n. 79.

Alcipe: 74 n. 67.

Alexandre: 7.

Anaxíbia: 35 n. 9; 72 n. 64.

Andrómeda: 7.

Anfitrite: 48.

Antestérias: 74 n. 69.

Antibóreas: 34 n. 5.

Antígona: 8.

Apolo: 11-12, 21, 23, 32, $36 \mathrm{n}$. 10,38 n. 12,40 n. 21,74 n. 65, 81 n. 78,82 n. $86,85,91$ n. 91 .

Apolónio de Rodes: 38 n. 11.

Aqueus: 9, 34, 52, 60.

Aquiles: 34, 40 n. 26, 46, 48, 53 n. $46,60,70$.

Ares: 74, 74 n. 67, 75, 98.

Argivas: 46.

Argo: 47 n. 36 .
Argos: 13, 35-36, 39, 40-41, 46$47,51,56-57,59-61,63-65$, 67, 69-70, 73, 76, 78, 85, 97.

Aristófanes: 7, 7 n. 2.

Aristóteles: 18, 20.

Ártemis: 9-12, 14-16, 20, 23, 24, 32-34, 34 n. 6, 36, 38 n. 12, n. 13 , n. 14,40 n. $23,41,64,66$, $76,81,81$ n. 81,82 n. 83,83 , 98, 98 n. 98, n. 100, n. 102.

Ártemis Braurónia: 24, 98 n. 100. Ártemis Parteira: 81.

As Troianas: 7.

Ásia: 47, 47 n. 36, 48 n. 43.

Astro da Manhá: 81 n. 79.

Atena: 15-16, 22-23, 32, 41 n. 27, 74 n. 68,75 n. 72, 97-99.

Atenas: 9, 16, 21, 24, 74, 75, $75 \mathrm{n}$. 72, 81, 98-99.

Atenienses: 24, 37, 74, 82.

Ática: 10, 15, 98.

Atreu: 9, 11, 33, 40 n. 23, 54, 67, 72, 76 n. 74 .

Atrida: 10, 38.

Atridas: 9-10, 15-16, 40, 40 n. 22, n. 23,71 .

Áulis: 9, 11-12, 34, 34 n. 5, 40, 45, 


$$
\text { 46, 53, 65, 68, 81, } 97 .
$$

Baco: 39, 74.

Beócia: 34 n. 5.

Bóreas: 34 n. 5.

Bósforo: 47 n. 36, 48 n. 40.

Bráuron: 10, 15, 15 n. 16, 38 n. 14, 98, 98 n. 101.

Braurónia, ver Ártemis Braurónia

Cadmo: 43 n. 29.

Calcas: 34, 53, 60.

Cantos Ciprios: 9.

Carístia: 98.

Cárites: 83.

Catálogo das Mulheres: 9 n. 8.

Ceíce: 81 n. 79.

Ciclopes: 69 n. 61.

Cidónia: 38 n. 13.

Cinto: 81, 91 n. 90.

Cítia: 32.

Clitemnestra: 9, 11, 19, 33 n. 4, 34, 40 n. 25, 41, 67 n. 56.

Coéforas: 39 n. 19.

Creta: 38 n. 13.

Crimeia: 34 n. 7.

Ctónia: 91.

Cypria: 10 n. 10.

Dánaos: 46.

Delfos: 23,75 n. 73,91 n. 91,91 n. 92 .

Delos: 81 n. 82, 91, 91 n. 90 .

Dicte: 38 n. 13.

Dictina: 38, 38 n. 13.

Dioniso: 91.
Dioscuros: 43.

Dirce: 47.

Dóris: 43 n. 31.

Egipto: 19, 47 n. 36.

Electra: 9, 21.

Electra: 9, 13, 39 n. 19, 55, 67, 71, 71 n. 62.

Eliano: 7.

Élide: 33 n. 2.

Enómao: 33, 33 n. 3, 68.

Éolo: 81 n. 79.

Épafo: 47 n. 36.

Erecteu: 75 n. 72.

Erínias: 12, 16, 21, 36, 44, 73-74, 74 n. $66,75,75$ n. $72,97-98$.

Esparta: 19, 47 n. 37, 52.

Ésquilo: 9, 17, 22, 39 n. 19, 75 n. 72.

Estrófio: 35, 72.

Euménides: 16.

Euménides: 75 n. 72.

Eurípides: 7-8, 8 n. 3, 9-11, 13-17, 19-23.

Euripo: 34.

Europa: 38, 47, 47 n. 36.

Eurotas: 47.

Febo: 36, 62, 73, 75, 82, 91.

Fineu: 48.

Fócida: 61 .

Geia: 91.

Gigantes: 41 n. 27.

Gluck: 24.

Goethe: 24 .

Graças: 83 n. 87. 
Grandes Dionísias: 7, 20.

Grécia: 10, 47 n. 36, 48 n. 43.

Guerra de Tróia: 19.

Guillard, François: 24.

Hades: 39, 44, 46, 49.

Halas: 11, 15, 98, 98 n. 98.

Halirrótio: 74 n. 67.

Hécuba: 21.

Hélade: 16, 22-23, 34, 36, 38, 45, $48,54,61-62,80,85-87,96$, 98-99.

Helena: 7-8, 18-19.

Helena: 34, 46, 48, 52.

Helenos: 12, 41-42, 49, 52, 81.

Hélio: 40.

Hémon: 8.

Hera: 41,43 n. 29,47 n. 36,81 n. 79 .

Héracles: 8.

Héracles Furioso: 8.

Hermes: 47 n. 36.

Heródoto: 10.

Heroon: 10.

Hesíodo: 9 n. 8.

Himeneu: 46, 70.

Hipodamia: 33 n. 3, 68.

Hipólito: 8.

Ifigénia: passim.

Ifigénia entre os Tauros: 7-9, 17-20, 23-24.

Ifigénia Táurica: 24.

Ifimede: 9.

Ilíada: 10.

Ino: 43 n. 29.
Io: 47 n. 36.

Íon: 7, 19.

Iphigenie auf Tauris: 24.

Iphigénie en Tauride: 24.

Jogos Olímpicos: 33 n. 3.

Leda: 40, 48.

Leto: 38, 46, 81, 90, 96.

Leucótea: 43, 43 n. 30.

Lóxias: 74, 76, 81, 92, 97.

Mar Negro: 10-11, 34 n. 7.

Medeia: 8, 21.

Mégara: 8.

Menelau: 33-34, 46, 52, 73.

Méon: 8.

Meras: 40, 40 n. 24.

Micenas: 51, 53, 57, 59, 69 n. 61, 75.

Musa: 39.

Musas: 82.

Náuplia: 67.

Nereide: 40, 48 n. 41, 53.

Nereides: 43, 43 n. 31.

Nereu: 43, 43 n. 31, 48.

Nerites: 43 n. 31.

Nice: 99.

Oceano: 43 n. 31.

Ocidente: 48 n. 43.

Odisseia: 10, 18.

Olimpo: 91.

Oresteia: 9, 23.

Orestes: 9, 11-16, 19, 21, 23, 32, passim.

Pã: 82,82 n. 85 . 


\section{Palamedes: 7.}

Palas: 41, 74-76, 99.

Palémon: 43.

Panateneias: 41 n. 27.

Parnaso: 91, 91 n. 90.

Passagem da Vaca: 47 n. 36.

Peleu: 46.

Pelópidas: 75, 96.

Pélops: 33, 33 n. 3, 40, 40 n. 22, 67-68.

Pílades: 12-13, 15, 21, 32, 35, 35 n. 9, 36-38, 42-44, 49-50, 57 n. 47, 59-60, 63 n. 52, 63 n. 53, 65, 71 n. 63, 79, 81, 90.

Pisa: 33, 68 .

Planctas: 38 n. 11.

Poética: 20.

Posídon: 33 n. 3, 48 n. 41, 74 n. 67, 96-97.

Rochas Negras: 64.

Sémele: 43 n. 29.

Simplégades: 16, 38 n. 11, 41, 43, 46,96 .

Sófocles: 17.

Sol: $45,68,82,88$.

Tantálida: 33.

Tantálidas: 40.

Tântalo: 46, 76, 76 n. 74.

Táurica: 12, 14, 21, 33, 98 n. 99.

Táurica, ver Ifigénia Táurica

Taurópola: 15, 98.

Tauros: 9-12, 14-16, 23, 32, 34, 83.

Tebas: 47 n. 38 .
Témis: 91.

Tétis: 40 n. 26, 53.

Tiestes: 67, 74 n. 76.

Tíndaro: 33 n. 4, 94.

Tínia: 48 n. 40.

Titanomaquia: 41 n. 27.

Titâs: 41, 41 n. 27.

Toas: 14-16, 21-23, 32, 34, 83, 83 n. 88,84 n. 89, 90, 92-93, 97-99.

Trácia: 48 n. 40.

Tróia: 10, 19, 38, 48, 52-53, $60 \mathrm{n}$. 49.

Ulisses: 18, 34, 53 n. 45.

Zéfiro: 48.

Zeus: 23,41 n. 27, 46-47, 47 n. $36,64,74,80,81$ n. 79, 90$92,96$. 


\section{TEXTOS GREGOS}

1. Delfim F. Leão e Maria do Céu Fialho: Plutarco. Vidas Paralelas - Teseu e Rómulo. Tradução do grego, introdução e notas (Coimbra, CECH, 2008).

2. Delfim F. Leão: Plutarco. Obras Morais - O banquete dos Sete Sábios. Tradução do grego, introdução e notas (Coimbra, CECH, 2008).

3. Ana Elias Pinheiro: Xenofonte. Banquete, Apologia de Sócrates. Tradução do grego, introdução e notas (Coimbra, CECH, 2008).

4. Carlos de Jesus, José Luís Brandão, Martinho Soares, Rodolfo Lopes: Plutarco. Obras Morais - No Banquete $I$ - Livros I-IV. Tradução do grego, introdução e notas. Coordenação de José Ribeiro Ferreira (Coimbra, CECH, 2008).

5. Ália Rodrigues, Ana Elias Pinheiro, Ândrea Seiça, Carlos de Jesus, José Ribeiro Ferreira: Plutarco. Obras Morais - No Banquete II - Livros V-IX. Traduçáo do grego, introdução e notas. Coordenação de José Ribeiro Ferreira (Coimbra, CECH, 2008).

6. Joaquim Pinheiro: Plutarco. Obras Morais - Da Educação das Crianças. Tradução do grego, introdução e notas (Coimbra, CECH, 2008).

7. Ana Elias Pinheiro: Xenofonte. Memoráveis. Tradução do grego, introdução e notas (Coimbra, CECH, 2009). 
8. Carlos de Jesus: Plutarco. Obras Morais - Diálogo sobre o Amor, Relatos de Amor. Tradução do grego, introdução e notas (Coimbra, CECH, 2009).

9. Ana Maria Guedes Ferreira e Ália Rosa Conceição Rodrigues: Plutarco. Vidas Paralelas - Péricles e Fábio Máximo. Tradução do grego, introdução e notas (Coimbra, CECH, 2010).

10. Paula Barata Dias: Plutarco. Obras Morais - Como Distinguir um Adulador de um Amigo, Como Retirar Benefício dos Inimigos, Acerca do Número Excessivo de Amigos. Tradução do grego, introdução e notas (Coimbra, CECH, 2010).

11. Bernardo Mota: Plutarco. Obras Morais - Sobre a Face Visivel no Orbe da Lua. Tradução do grego, introdução e notas (Coimbra, CECH, 2010).

12. J. A. Segurado e Campos: Licurgo. Oração Contra Leócrates. Tradução do grego, introdução e notas (Coimbra, CECH /CEC, 2010).

13. Carmen Soares e Roosevelt Rocha: Plutarco. Obras Morais - Sobre o Afecto aos Filhos, Sobre a Música. Tradução do grego, introdução e notas (Coimbra, $\mathrm{CECH}, 2010)$.

14. José Luís Lopes Brandão: Plutarco. Vidas de Galba e Otão. Tradução do grego, introdução e notas (Coimbra, CECH, 2010).

15. Marta Várzeas: Plutarco. Vidas de Demóstenes e Cícero. Tradução do grego, introdução e notas (Coimbra, $\mathrm{CECH}, 2010)$. 
16. Maria do Céu Fialho e Nuno Simóes Rodrigues: Plutarco. Vidas de Alcibiades e Coriolano. Traduçáo do grego, introdução e notas (Coimbra, CECH, 2010).

17. Glória Onelley e Ana Lúcia Curado: Apolodoro. Contra Neera. [Demóstenes] 59. Tradução do grego, introdução e notas (Coimbra, CECH, 2011).

18. Rodolfo Lopes: Platão. Timeu-Critías. Tradução do grego, introdução e notas (Coimbra, CECH, 2011).

19. Pedro Ribeiro Martins: Pseudo-Xenofonte. A Constituição dos Atenienses. Tradução do grego, introdução, notas e índices (Coimbra, CECH, 2011).

20. Delfim F. Leão e José Luís L. Brandão: Plutarco. Vidas de Sólon e Publicola. Tradução do grego, introdução, notas e índices (Coimbra, CECH, 2012).

21. Custódio Magueijo: Luciano de Samósata I. Tradução do grego, introdução e notas (Coimbra, CECH/IUC, 2012).

22. Custódio Magueijo: Luciano de Samósata II. Tradução do grego, introdução e notas (Coimbra, CECH/IUC, 2012).

23. Custódio Magueijo: Luciano de Samósata III. Tradução do grego, introdução e notas (Coimbra, CECH/IUC, 2012).

24. Custódio Magueijo: Luciano de Samósata IV. Tradução do grego, introdução e notas (Coimbra, CECH/IUC, 2013). 
25. Custódio Magueijo: Luciano de Samósata $V$. Tradução do grego, introdução e notas (Coimbra, CECH/IUC, 2013).

26. Custódio Magueijo: Luciano de Samósata VI. Tradução do grego, introdução e notas (Coimbra, CECH/IUC, 2013).

27. Custódio Magueijo: Luciano de Samósata VII. Tradução do grego, introdução e notas (Coimbra, CECH/IUC, 2013).

28. Custódio Magueijo: Luciano de Samósata VIII. Tradução do grego, introdução e notas (Coimbra, CECH/IUC, 2013).

29. Custódio Magueijo: Luciano de Samósata IX. Tradução do grego, introdução e notas (Coimbra, CECH/IUC, 2013).

30. Reina Marisol Troca Pereira: Hiérocles e Filágrio. Philogelos (O Gracejador). Tradução do grego, introdução e notas (Coimbra, CECH/IUC, 2013).

31. J. A. Segurado e Campos: Iseu. Discursos. VI. A herança de Filoctémon. Tradução do grego, introdução e notas (Coimbra, CECH/IUC, 2013).

32. Nelson Henrique da Silva Ferreira: Aesopica: a fábula esópica e a tradição fabular grega. Estudo, tradução do grego e notas. (Coimbra, CECH/IUC, 2013).

33. Carlos A. Martins de Jesus: Baquílides. Odes e Fragmentos Tradução do grego, introdução e notas (Coimbra e São Paulo, IUC e Annablume, 2014). 
34. Alessandra Jonas Neves de Oliveira: Eurípides. Helena. Tradução do grego, introdução e notas (Coimbra e São Paulo, IUC e Annablume, 2014).

35. Maria de Fátima Silva: Aristófanes. Rãs. Tradução do grego, introdução e notas (Coimbra e São Paulo, IUC e Annablume, 2014).

36. Nuno Simóes Rodrigues: Eurípides. Ifigénia entre os Tauros. Tradução do grego, introdução e notas (Coimbra e São Paulo, IUC e Annablume, 2014). 
IMPRESSÃO:

Artipol - Artes tipográficas, Lda.

Zona industrial de Mourisca do Vouga, Apartado 3051 3754-901 ÁguedA 
Eurípides terá composto e produzido a Ifgénia entre os Tauros entre a trilogia troiana de 415 e a Helena de 412 a.C., provavelmente em 414 ou 413 a.C., sendo, portanto, contemporânea de Alcibíades. Esta tragédia inclui-se naquelas que preferem os temas construídos sobre as relaçôes familiares, sem que delas, porém, se evidencie o factor crime ou que, pelo menos, esse não tenha o protagonismo do enredo. $\mathrm{O}$ argumento parte da tradição que considerava que a jovem Ifigénia, afinal, não tinha morrido no altar do sacrifício, em Áulis. Uma importante inovação da tradição mitológica introduzida por Eurípides neste texto é a figura de Orestes, que não fazia propriamente parte do ciclo centrado em Ifigénia e Ártemis e que aqui tem um papel determinante. Assim, a peça abre com uma Ifigénia exilada em terras bárbaras, onde desempenha a funçấo de sacerdotisa de Ártemis, deusa que assume o seu carácter sanguinário, pois exige o sacrifício dos estrangeiros que ali chegam. O dilema trágico revela-se quando, na Táurica, aparecem dois estrangeiros, que a sacerdotisa deve sacrificar à deusa, mas que afinal sáo o próprio irmão e o primo de Ifigénia. A Atrida terá de escolher entre matar os familiares e assim cumprir as obrigaçóes religiosas a que está obrigada, ou transgredir as normas e salvar aqueles a quem está unida por sangue e afecto. 


\section{OBRA PUBLICADA \\ COM A COORDENAÇÁO \\ CIENTÍFICA}

0

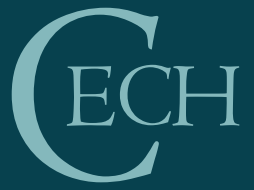

Centro de Estudos

Clássicos e Humanísticos

Da UNIVErstiade DE CoImbra

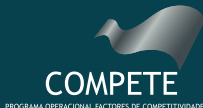

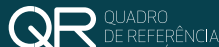
ESTRATÉGICO
$\square$ NACIONAL

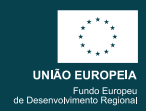

\section{ardene}

de Desenvolviminentio Regogonal 